\title{
Beyond First-Line Immunotherapy: Potential Therapeutic Strategies Based on Different Pattern Progressions: Oligo and Systemic Progression
}

\author{
Arsela Prelaj 1,2,*,+iD, Chiara Carlotta Pircher ${ }^{1,+}$, Giacomo Massa ${ }^{1,+}$, Valentino Martelli ${ }^{3}$, Giulia Corrao ${ }^{4,5}$, \\ Giuseppe Lo Russo ${ }^{1}$, Claudia Proto ${ }^{1}$, Roberto Ferrara ${ }^{1}$, Giulia Galli ${ }^{1}$, Alessandro De Toma ${ }^{1}$, Carlo Genova ${ }^{6,7}$ (D), \\ Barbara Alicja Jereczek-Fossa ${ }^{4,5}$, Filippo de Braud ${ }^{1}$, Marina Chiara Garassino ${ }^{1}$ and Sara Elena Rebuzzi ${ }^{3,7}$ (D)
}

\section{check for} updates

Citation: Prelaj, A.; Pircher, C.C.; Massa, G.; Martelli, V.; Corrao, G.; Lo Russo, G.; Proto, C.; Ferrara, R.; Galli, G.; De Toma, A.; et al. Beyond First-Line Immunotherapy: Potential Therapeutic Strategies Based on Different Pattern Progressions: Oligo and Systemic Progression. Cancers 2021, 13, 1300. https://doi.org/ 10.3390/cancers13061300

Academic Editor: Geeta Upadhyay

Received: 6 February 2021

Accepted: 11 March 2021

Published: 15 March 2021

Publisher's Note: MDPI stays neutral with regard to jurisdictional claims in published maps and institutional affiliations.

Copyright: (c) 2021 by the authors. Licensee MDPI, Basel, Switzerland. This article is an open access article distributed under the terms and conditions of the Creative Commons Attribution (CC BY) license (https:/ / creativecommons.org/licenses/by/ $4.0 /)$.
1 Medical Oncology Department, Fondazione IRCCS Istituto Nazionale Tumori, via Giacomo Venezian 1, 20133 Milan, Italy; chiara.pircher@istitutotumori.mi.it (C.C.P.); giacomo.massa@istitutotumori.mi.it (G.M.); Giuseppe.LoRusso@istitutotumori.mi.it (G.L.R.); Claudia.proto@istitutotumori.mi.it (C.P.); roberto.ferrara@istitutotumori.mi.it (R.F.); giulia.galli@isitutotumori.mi.it (G.G.); alessandro.detoma@istitutotumori.mi.it (A.D.T.); filippo.debraud@istitutotumori.mi.it (F.d.B.); marina.garassino@istitutotumori.mi.it (M.C.G.)

2 Department of Electronics, Information, and Bioengineering, Polytechnic University of Milan, Piazza Leonardo Da Vinci 32, 20133 Milan, Italy

3 Oncologia Medica 1, IRCCS Ospedale Policlinico San Martino, Largo Rosanna Benzi 10, 16132 Genova, Italy; valentino.martelli@hsanmartino.it (V.M.); s4235190@studenti.unige.it or saraelena89@hotmail.it (S.E.R.)

4 Division of Radiation Oncology, IEO, European Institute of Oncology IRCCS, via Ripamonti 435, 20141 Milan, Italy; giulia.corrao@ieo.it (G.C.); barbara.jereczek@ieo.it (B.A.J.-F.)

5 Department of Oncology and Hemato-Oncology, University of Milan, via Festa del Perdono, 7, 20122 Milan, Italy

6 UO Clinica di Oncologia Medica, IRCCS Ospedale Policlinico San Martino, Largo Rosanna Benzi 10, 16132 Genova, Italy; carlo.genova@hsanmartino.it

7 Dipartimento di Medicina Interna e Specialità Mediche (DiMI), Università degli Studi di Genova, Viale Benedetto XV 6, 16132 Genoa, Italy

* Correspondence: arsela.prelaj@istitutotumori.mi.it; Tel.: +39-32-9218-7197; Fax: +39-0-2390-2149

+ These authors contributed equally to this work.

Simple Summary: The aim of this innovative review is to highlight the treatment strategies beyond immune-checkpoint inhibitor (ICI)-based first-line therapy failure according to different patterns of progression (i.e., oligo or systemic progression) and to discuss the ongoing and potential future therapeutic approaches to overcome resistance to immunotherapy. Many therapeutic strategies can be adapted in advanced non-small cell lung cancer patients with oligo and systemic progression to personalize the treatment approach based on to re-characterization of the tumors, previous ICI response and type of progression.

Abstract: First-line immune-checkpoint inhibitor (ICI)-based therapy has deeply changed the treatment landscape and prognosis in advanced non-small cell lung cancer (aNSCLC) patients with no targetable alterations. Nonetheless, a percentage of patients progressed on ICI as monotherapy or combinations. Open questions remain on patients' selection, the identification of biomarkers of primary resistance to immunotherapy and the treatment strategies to overcome secondary resistance to first-line immunotherapy. Local ablative approaches are the main therapeutic strategies in oligoprogressive disease, and their role is emerging in patients treated with immunotherapy. Many therapeutic strategies can be adapted in aNSCLC patients with systemic progression to personalize the treatment approach according to re-characterization of the tumors, previous ICI response, and type of progression. This review's aim is to highlight and discuss the current and potential therapeutic approaches beyond first-line ICI-based therapy in aNSCLC patients based on the pattern of disease progression (oligoprogression versus systemic progression). 
Keywords: non-small cell lung cancer; oligoprogression; immune checkpoint inhibitor; immunotherapy; local therapy; resistance

\section{Introduction}

In recent years, immune checkpoint inhibitors (ICIs) have dramatically changed the treatment landscape of advanced non-small cell lung cancer (aNSCLC). Most aNSCLC patients do not harbor a targetable alteration (non-oncogene aNSCLC); thus, immunotherapy, as single agent or in combination with other drugs (immuno-chemotherapy (CT) ICI-CT-or immuno-immunotherapy-ICI-ICI) are the mainstay treatment based on the programmed death-ligand 1 (PD-L1)'s expression [1,2].

Despite the survival advantage, only a percentage of aNSCLC patients respond to single-agent ICI (20-30\%) and ICI-based combinations (50-60\%), while most patients experience disease progression [1,2]. The treatment choice after failure of first-line ICI-based therapy depends on previous treatment, type of response and progression, the burden of disease, and patient performance. Several unanswered questions include patients' selection and the identification of prognostic and predictive biomarkers of primary and secondary resistance to ICIs. The establishment of therapeutic strategies to overcome failure of ICIsand to extend its benefit in non-responding and progressing patients is a clinical unmet need and a critical area of research [3,4].

This review aimed to highlight the treatment strategies beyond failure ICI-based first-line therapy according to different patterns of progression (i.e., oligo or systemic progression) and to discuss the ongoing and potential future therapeutic approaches to overcome resistance to immunotherapy.

\section{Definition and Biology of Oligoprogression in aNSCLC}

The term "oligoprogression" refers to the progression of a limited number of metastatic lesions in the context of a well-controlled metastatic disease [2,5]. This concept is related to the wider definition of "oligometastatic" disease ("oligo" = "few") that refers to a limited number of metastases and/or metastatic sites characterized by a more indolent behavior than a polymetastatic disease $[5,6]$. Although there is no consensus on the appropriate cut off to define the oligometastatic state, generally up to $3-5$ lesions in 1-3 organs are defined in international guidelines and are commonly accepted [7-9].

The most available evidence for oligoprogression is reported in aNSCLC patients treated with tyrosine kinase inhibitors (TKIs). Their inter- and intra-tumors heterogeneity are the biological basis of this clinical scenario.

Tyrosine kinase inhibitors selectively favor tumor clones that are intrinsically resistant (primary resistance) or induce changes in tumors' phenotype (secondary resistance) [5]. Few studies are available regarding oligoprogression on ICI-treated patients. In this case, oligoprogression might represent local immune tolerance, even though mechanisms of resistance are more heterogeneous and are not well-defined [10].

The incidence of oligoprogression is $15-47 \%$ with TKI and $10-20 \%$ with ICI or ICIbased combinations [11-13]. The most common oligometastatic and oligoprogressive sites include brain, lung, lymph nodes, liver, and adrenal glands [13,14].

\section{Local Ablative Therapies in Oligoprogressive aNSCLC}

Many studies have been conducted on the efficacy and safety of local ablative therapies (LAT), including radiotherapy (RT), surgery, and radiofrequency ablation (RFA), in oligometastatic and oligoprogressive aNSCLC patients $[5,10,15]$.

In the oligometastatic disease, such approaches could be potentially curative, while in oligoprogressive patients they allow to eliminate foci of resistance, continue systemic treatment and postpone further therapies increasing disease control and overall survival (OS) $[5,10,15]$. 
Radiotherapy, especially stereotactic body radiation therapy (SBRT), is the most used and studied LAT for cranial and extra-cranial metastases, as it is non-invasive, welltolerated, and permits fewer interruptions of systemic therapy $[5,10,15]$.

In ICI-treated patients, RT is the most promising LAT in oligoprogressive patients for its synergistic effect on enhancing the anti-tumor action of the immune system and overcoming ICIs' resistance $[16,17]$. These pathogenetic mechanisms are the basis of the abscopal effect, a rare event consisting of an immune-mediated response to RT of metastases distant from the irradiated site (from "ab scopus", i.e., "away from the target") [16]. Multiple questions remain regarding optimal patient selection, choice of RT schedule, and sequencing between RT and systemic therapy [16].

The second most important LAT is surgery (metastasectomy). However, its efficacy was shown to improve with the combination of other techniques, especially RT $[10,18]$. The strongest evidence in LAT surgery refers to brain metastases surgery, while the evidence lacks in extracranial metastases, which include mainly lung and adrenal gland ones $[10,18]$. Other LATs, with less evidence, including RFA and cryoablation, especially on lung and liver metastases $[10,18]$.

\section{Local Ablative Therapies in Oligoprogressive aNSCLC Treated with ICIs \\ 4.1. Current Evidence}

Local ablative therapies represent a consolidated approach in oligoprogressive oncogene-addicted aNSCLC, but its role in immunotherapy has been poorly addressed. Although this therapeutic strategy is not a standard approach with ICIs, its use in clinical practice is an extrapolation of data from patients treated with CT or TKI.

Few case reports on oligoprogression of ICI-treated aNSCLC patients showed that LAT (RT and/or surgery) continuing immunotherapy beyond progression was associated with successful disease control and long-term survival benefit [19-21]. The clinical evidence on LAT in oligoprogressed ICI-treated aNSCLC patients comes mainly from retrospective analysis (Table 1) [13,22-26].

In 2016, Bledsoe et al. [22] reported that RT for oligoprogressive lesions was safe and offered good local control at months 6 and 12 in $92 \%$ and $85 \%$ of 21 aNSCLC patients receiving ICIs.

In a retrospective analysis on 81 ICI-treated patients, oligoprogression was observed in approximately $10 \%$ of progressed patients, and $50 \%$ of them received LAT with durable clinical benefit [23].

A higher number of oligoprogression ( $88 \%$ ) was reported by Gettinger et al. [24] among 26 aNSCLC patients progressing on ICIs. A similar percentage of patients (58\%) received LAT (mainly RT) to oligoprogressive site(s), and $73 \%$ of patients continued immunotherapy with prolonged benefit. Similarly, another analysis, on 27 aNSCLC patients treated with LAT (RT and surgery) for oligoprogression on anti-PD-1 agents, reported that ICI was continued beyond progression in 22 patients ( $81 \%$ ) and mPFS (median Progression-Free Survival) after LAT was 13.2 months [25].

In a larger retrospective study (100 patients progressing on pembrolizumab), $18(18 \%)$ patients were treated beyond progression and among them, 13 patients $(72 \%)$ had oligoprogression and nine $(69 \%)$ patients were treated with the addition of RT [26]. The combination of pembrolizumab beyond progression and RT was associated with high postprogression survival.

Recently, Rheinheimer et al. [13] conducted a retrospective analysis on 372 aNSCLC patients treated with ICI-based therapy (ICI alone or in combinations with other drugs). About $13 \%$ of patients developed oligoprogression and LATs were more frequently offered to patients with brain metastases than extracranial cases ( $72 \%$ versus $49 \%$ ). Moreover, LATs were more frequently used in patients treated with ICI-CT compare to ICI monotherapy $(90 \%$ versus $50 \%)$. 
Table 1. Current evidence on local ablative therapy (LAT) in advanced non-small cell lung cancer (aNSCLC) patients who oligoprogressed on immune-checkpoint inhibitors (ICI)

\begin{tabular}{|c|c|c|c|c|c|c|c|c|c|c|c|}
\hline Author (Year) & $N$ Patients & ICI & ICI Line & $\begin{array}{l}\text { Time to } \\
\text { Progression } \\
\text { (Months) }\end{array}$ & $\begin{array}{l}\text { Oligoprogressive } \\
\text { Site for LAT }\end{array}$ & Treatment Strategy & LAT & $\begin{array}{l}\text { Best Disease } \\
\text { Response }\end{array}$ & $\begin{array}{l}\text { Time from } \\
\text { Progression } \\
\text { (Months) }\end{array}$ & $\begin{array}{l}\text { PFS from } \\
\text { ICI } \\
\text { (Months) }\end{array}$ & $\begin{array}{l}\text { OS from ICI } \\
\text { (Months) }\end{array}$ \\
\hline \multicolumn{12}{|c|}{ Case report } \\
\hline $\begin{array}{l}\text { Griswold } \\
\text { (2019) }\end{array}$ & - & Pembrolizumab & I & 2 & Subcutaneous lesions & $\begin{array}{c}\text { LAT plus } \\
\text { continuing ICI }\end{array}$ & Surgery & Stable disease & $\geq 12$ & $\geq 15$ & $\geq 15$ \\
\hline Sotelo (2020) & - & Nivolumab & II & 12 & Adrenal lesion & $\begin{array}{c}\text { LAT plus } \\
\text { continuing ICI }\end{array}$ & SBRT & $\begin{array}{c}\text { Partial } \\
\text { response }\end{array}$ & $\geq 29$ & $\geq 41$ & $\geq 41$ \\
\hline Tobita (2020) & - & Nivolumab & III & $\begin{array}{l}17^{\mathrm{a}} \\
6^{\mathrm{b}}\end{array}$ & $\begin{array}{c}\text { Bone metastasis }{ }^{\mathrm{a}} \\
\text { small intestine } \\
\text { lesion }^{\mathrm{b}}\end{array}$ & $\begin{array}{l}\text { LAT plus } \\
\text { continuing ICI }\end{array}$ & $\begin{array}{c}\mathrm{RT}^{\mathrm{a}}, \\
\text { surgery }\end{array}$ & Stable disease & $\begin{array}{c}6^{\mathrm{a}} \\
\geq 18^{\mathrm{b}} \\
\end{array}$ & $\begin{array}{l}23^{\text {a }} \\
\geq 41 \\
\end{array}$ & $\geq 47$ \\
\hline \multicolumn{12}{|c|}{ Retrospective } \\
\hline Bledsoe (2016) & 21 & ICIs & - & median $=2.7$ & Bone, brain, lung & $\begin{array}{l}\text { LAT plus continuing } \\
\text { ICI }(29 \%)\end{array}$ & RT & $\begin{array}{c}\text { LC at } 6 \text { and } \\
12 \text { months }= \\
92 \%, 85 \%\end{array}$ & median $=2.3$ & - & $\mathrm{mOS}=7.2$ \\
\hline $\begin{array}{l}\text { Mersiades } \\
(2017)\end{array}$ & $\begin{array}{c}10 \\
(5 \text { received LAT) }\end{array}$ & $\begin{array}{l}\text { Pembrolizumab, } \\
\text { nivolumab }\end{array}$ & II & median $=20.2$ & - & $\begin{array}{l}\text { LAT plus continuing } \\
\text { ICI }(70 \%)\end{array}$ & RT & $\mathrm{LC}$ & - & - & $\begin{array}{c}\text { mOS after } \\
\text { progression: } 11.44\end{array}$ \\
\hline $\begin{array}{l}\text { Gettinger } \\
(2018)\end{array}$ & $\begin{array}{c}26 \\
\text { (15 received LAT) }\end{array}$ & $\begin{array}{c}\text { ICIs } \\
\text { (monotherapy, } \\
\text { combination) }\end{array}$ & - & median $=10.3$ & $\begin{array}{l}\text { Lymph node, adrenal, } \\
\text { brain, lung }\end{array}$ & $\begin{array}{l}\text { LAT plus continuing } \\
\text { ICI }(73 \%)\end{array}$ & - & - & - & - & $\begin{array}{c}\mathrm{mOS}=\mathrm{NR} \\
2 \text { year OS }=92 \%\end{array}$ \\
\hline Metro (2019) & $\begin{array}{c}13 \\
\text { (9 received LAT) }\end{array}$ & Pembrolizumab & I & - & $\begin{array}{l}\text { Brain, lung, } \\
\text { lymph node, kidney }\end{array}$ & $\begin{array}{c}\text { LAT plus } \\
\text { continuing ICI }\end{array}$ & RT & - & $\begin{array}{c}\text { PPS at } 6 \\
\text { and } 12 \text { months } \\
=89 \%, 71.1 \%\end{array}$ & - & - \\
\hline $\begin{array}{l}\text { Rheinheimer } \\
\quad(2020)\end{array}$ & $\begin{array}{c}48 \\
\text { (28 received LAT) }\end{array}$ & $\begin{array}{c}\text { ICIs } \\
\text { (monotherapy, } \\
\text { combination) }\end{array}$ & $\geq \mathrm{I}$ & Range 4-11 & $\begin{array}{l}\text { Brain, lung, } \\
\text { lymph node }\end{array}$ & - & $\begin{array}{l}\text { RT, } \\
\text { surgery }\end{array}$ & - & median: 14 & - & $16 \mathrm{NR}$ \\
\hline Kroeze (2019) & $\begin{array}{c}108 \\
(31 \% \text { received ICI) }\end{array}$ & $\begin{array}{c}\text { Nivolumab, } \\
\text { pembrolizumab }\end{array}$ & - & - & $\begin{array}{l}\text { Extracranial or } \\
\text { cranial lesions }\end{array}$ & $\begin{array}{l}\text { LAT plus continuing } \\
\text { ICI/TKI }\end{array}$ & SBRT & $\begin{array}{l}\mathrm{LC}=12 \\
\text { months }\end{array}$ & $\begin{array}{c}\text { At } 1 \mathrm{y} \\
47 \% \text { of pts } \\
\text { continued ICI }\end{array}$ & 7 & $\begin{array}{c}\text { Improved mOS } \\
p=0.008\end{array}$ \\
\hline
\end{tabular}

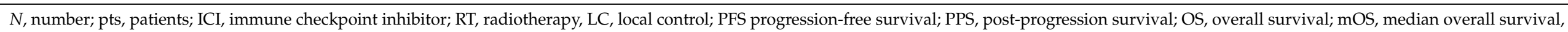

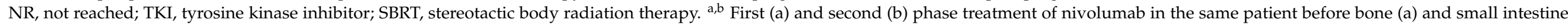
(b) progression. 
Finally, a retrospective international multicenters register study (TOaSTT) collected data on NSCLC patients who received SBRT and systemic therapy based on ICI/TKI. A total of 192 lesions on 108 patients were analyzed. Of the latter, 60\% received TKI, while 31\% received ICI and $8 \%$ bevacizumab (antiangiogenic drug). Oligoprogressive and oligopersistent (patients with an existing oligometastasis at baseline) patients showed significant improvement in OS. The PFS was superior in the oligoprogressive group (20.1 versus 7 versus 4.4 months, respectively) [27].

All these studies showed that for oligoprogressive aNSCLC patients treated with immunotherapy, LAT associated with continuation immunotherapy beyond PD appeared to be a safe therapeutic option providing promising long-term survival. However, despite the encouraging data, most of these studies are small retrospective analyses and larger prospective studies are needed.

\subsection{Ongoing Trials}

In addition to the abovementioned analyses (Section 4.1), there are several ongoing prospective clinical trials assessing the addition of RT to oligoprogressive ICI-treated aNSCLC patients (Table 2).

Two studies are evaluating the efficacy and safety of the combination of a PDL1 inhibitor (avelumab or atezolizumab) and RT after progression on a PD-1 inhibitor (nivolumab or pembrolizumab) (NCT03158883, NCT04549428).

The UCDCC\#270 is an early phase I single-center study which the aim of assessing the combination of avelumab and SBRT in 26 participants divided into "non-responders" and "progressors" to immunotherapy who previously failed platinum-based CT (NCT03158883).

A similar study is the NCT04549428 trial, a multicenter phase II, single-arm study evaluating the combination of atezolizumab with palliative RT (8 Gy single-fraction) in aNSCLC patients who oligoprogressed ( $\leq 4$ lesions) upon monoimmunotherapy received in sequence after CT or in combination with CT.

In both studies, the primary endpoint is the objective response rate (ORR), while OS and progression-free survival (PFS) are secondary endpoints.

Five other ongoing trials are designed to evaluate the efficacy and safety of the RT and ICI combination in patients with oligoprogressive disease continuing the same ICI beyond PD.

The SUPPRESS-NSCLC study is a phase II trial which will randomize 68 aNSCLC patients who oligoprogressed ( $\leq 5$ lesions) on ICI or TKI (at any line) to receive SBRT while continuing the current systemic therapy versus standard of care (begin next-line systemic therapy, best supportive care, continue current systemic line) (NCT04405401).

Another randomized trial is the phase II NCT04485026 study designed to evaluate the efficacy of local consolidative RT versus second-line therapy in aNSCLC patients who oligoprogressed ( $\leq 4$ lesions) on ICI-based first-line therapy after having experienced response or stable disease.

The NCT03693014 is an additional phase II monocentric trial assessing the efficacy of hypofractionated RT in oligoprogressive ICI-treated patients. Unlike other studies, this trial will include different advanced tumors types, including aNSCLC, treated with different ICIs. The enrolled patients must have evidence of limited progression ( $\leq 5$ lesions) and will receive SBRT to a maximum of three lesions, while continuing immunotherapy, the hypofractionated RT seems to be more immunogenic.

The phase II NCT03406468 trial will assess the efficacy of RT to a single lesion in 40 aNSCLC patients who progressed on ICI monotherapy or ICI-CT combination and have previously achieved stable disease or response to immunotherapy.

Finally, the NCT04492969 trial will be the largest study (320 estimated participants) with the aim to prospectively evaluate the pattern progression in aNSCLC patients after response to ICI. Moreover, the feasibility and clinical value of RT in oligoprogressive lesions (1-3 lesions in 1-2 organs) after ICI will be investigated. 
Table 2. Ongoing trials on LAT in advanced NSCLC patients who progressed on ICI.

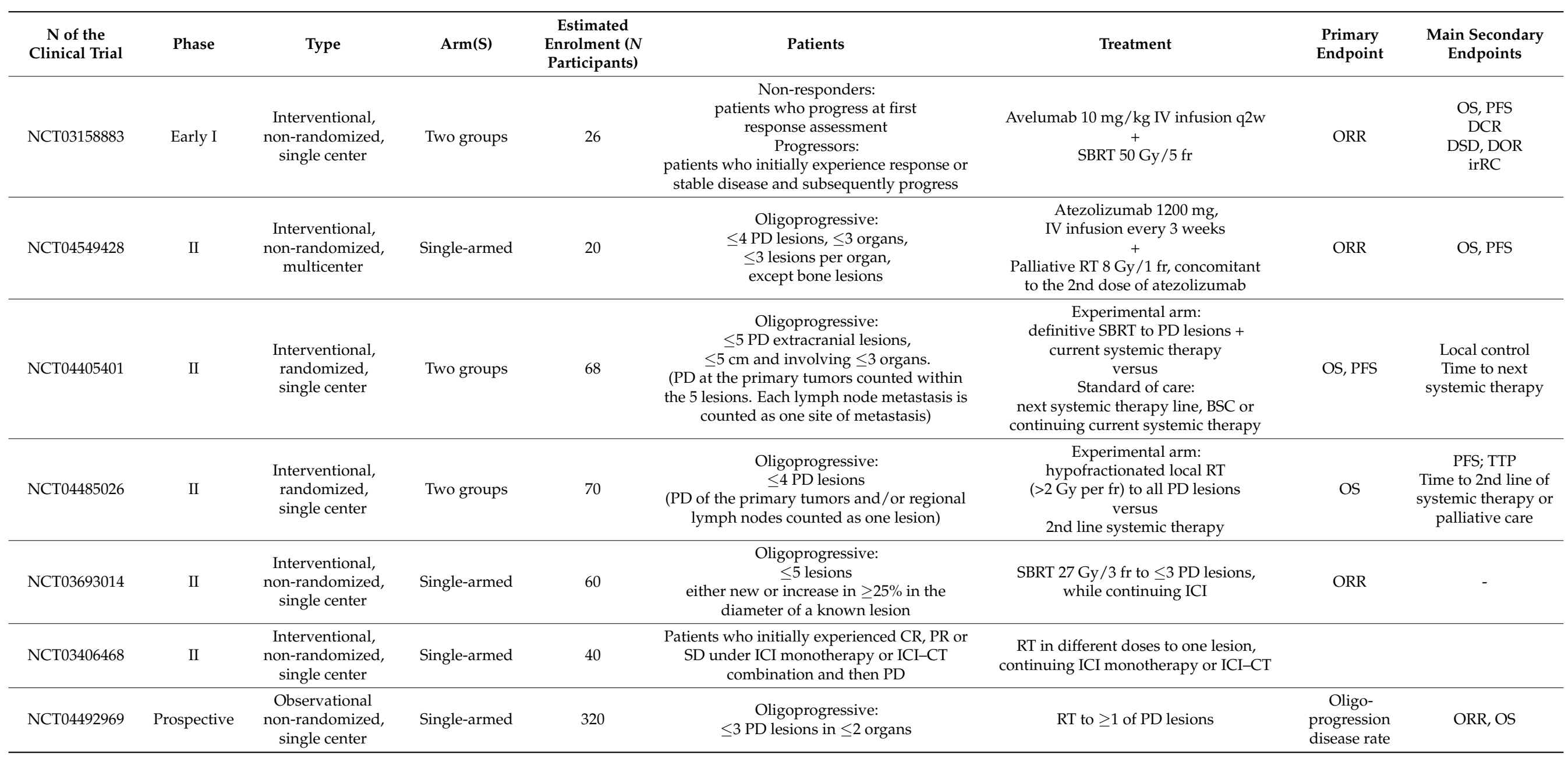

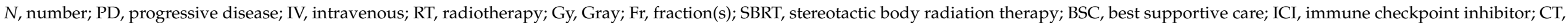

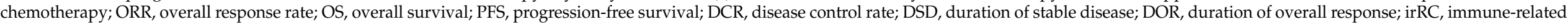

response criteria; TTP, time to progression. 
Oligoprogression in aNSCLC patients treated with immunotherapy is an uncommon finding in clinical practice; however, researchers show an increasing interest in this setting, since it can be associated with a good prognosis if treated properly. This is reflected in the growing number of ongoing or planned clinical trials even though large multicenter, randomized, phase III clinical trials are still needed.

\section{Systemic Progression}

\subsection{Timing of Systemic Progression}

In this review, systemic progression on ICI-CT was divided into three categories based on the timing of progression: early systemic progression (ES-PD), characterized by the lack of response to immunotherapy and a disease progression occurring within the first 3 months of treatment initiation; intermediate systemic progression (IS-PD) defined as a disease progression occurring between 3 months and 2 years from the start of treatment; late systemic progression (LS-PD) defined as a disease progression occurring at least after 2 years of ICI treatment.

The biological mechanisms underlying resistance to immunotherapy are not well defined and the complexity of the tumors microenvironment (TME) and the immune system is translated into different types and mechanisms of ES-PD [28].

\subsection{Early Progression Mechanisms and Definitions}

The immune escape mechanisms underlying primary resistance to immunotherapy are present at baseline immunotherapy and regard the defective "ignition" (priming defective mechanism) or the development and consolidation (adaptive immune resistance) of the immune response $[29,30]$ (Table 3 ).

Table 3. Definition of different types of resistance to immunotherapy.

A clinical scenario where cancer does not respond to an immunotherapy strategy.

Primary resistance The mechanistic basis of lack of response to immunotherapy may include adaptive immune resistance or a defect in antigen presentation and initiation of the immune response. Acquired resistance $\quad$ A clinical scenario in which cancer initially responded to immunotherapy but after a period of time it
relapsed and progressed.

\begin{tabular}{c}
$\begin{array}{c}\text { Cancer is not recognized by the immune system (defective priming). } \\
\text { Priming defective } \\
\text { mechanism }\end{array}$ \\
$\begin{array}{c}\text { This could clinically manifest as primary resistance; rarer is a priming defect as the exclusive mechanism } \\
\text { in acquired resistance because there are several active T cell clones. }\end{array}$ \\
$\begin{array}{c}\text { Adaptive immune } \\
\text { resistance }\end{array}$ \\
$\begin{array}{c}\text { A mechanism of resistance where cancer is recognized by the immune system (correct priming) but it } \\
\text { protects itself by adapting to the immune attack (defective development and consolidation of the } \\
\text { immune response) }\end{array}$ \\
this could clinically manifest as primary resistance, mixed responses or acquired resistance. \\
\hline
\end{tabular}

On the contrary, the acquired resistance to immunotherapy develops after the acquisition of new tumors escape mechanisms during treatment after an initial phase of response or stable disease (secondary resistance) $[24,28]$.

These mechanisms concern the decreased production and expression of tumors antigens (e.g., human leukocyte antigen (HLA) class I defects [31,32]), epigenetic modifications [33,34], genetic mutations (e.g., mutations of MAPK pathway [35], loss of PTEN [36] with an increase of PI3K [37,38], expression of WNT/ $\beta$-catenin [39], altered IFN- $\alpha$ pathway [40], EGFR mutations [41], MYC overexpression [42]), alterations of PDJ amplicon on chromosome 9, which codes for PD-L1/2 and JAK2, and alterations of a gene set called IPRES [43], related to a mesenchymal transformation [28]. The intrinsic mechanisms inclued also TME alteration, including molecules and cells of the tumor stroma, immune-regulatory cell (Tregs [44], MDSCs [45], M2 macrophages [46]), immune checkpoints. And soluble molecules, such as IFN- $\alpha$, which leads to the production of IDO [47] and CEACAM-1 [28,48]. 
Clinical studies are lacking in describing resistance mechanisms ICI-CT combination and also data indicating for treatment beyond progression on first-line ICI-CT is currently limited [49-53].

\subsection{Hyperprogression and Fast Progression}

Hyperprogressive disease (HPD) is described as the acceleration of the disease progression during ICI compared to the natural history of the tumors, associated with a rapid worsening of clinical conditions within the first imaging evaluation and poor prognosis [54]. Specific criteria were identified by Lo Russo et al. [55] and are used in clinical practice for the definition of HPD. Despite it, the biological mechanisms are still unknown, HPD has become an emerging clinical issue in the immunotherapy era [54]. Its prevalence is 10-20\% in ICI-treated aNSCLC and most literature evidence regard single-agent ICI, while few data are available with the ICI-based combinations and its prevalence $[55,56]$. To date, HPD did not seem to correlate with a particular patient, tumor or treatment characteristic, and no predictive markers are available $[57,58]$.

A different clinical entity described is fast progression (FP), which is a progression within the first radiologic evaluation or no later than 12 weeks but not classifiable as HPD criteria [59]. According to some small evidence on the biological mechanisms, HPD is associated with a disimmunity, while FP is associated with primary resistance to immunotherapy $[28,55,59]$.

No specific therapies exist for HPD or FP patients. Chemotherapy, TKI, clinical trial or best supportive care are currently the only possible treatment options. Re-biopsy to search for targetable alterations as resistance mechanisms or histology transformation should be considered for treatment decision and also for implementing biological knowledge about this phenomenon [60-62].

We are going to describe the major recent studies on the systemic strategies for ES-PD patients treated with ICI-CT.

\section{Treatment Option Strategies for Early Systemic Progression}

In this section, we reported different strategies for overcoming resistance that leads to ES-PD and IS-PD including (1) strategies with immunotherapy, (2) strategies beyond immunotherapy, and (3) innovative trials with different multiple approaches.

\subsection{Strategies with Immunotherapy}

The therapeutic strategies with the use of immunotherapy beyond progression included the use of (1) second-generation immunotherapeutic agents, (2) the combination of immunotherapy with antiangiogenic agents, and (3) the combination of immunotherapeutic agents.

\subsubsection{Second-Generation Immunotherapeutic Agents \\ IL-2 Agonist}

The immune-stimulating activity of the cytokine IL-2 is well-known and NKTR-214 (Bempegaldesleukin) is an IL-2 agonist targeting CD122 receptor, which is the IL2 receptor $\beta$-subunit, found on the surface of CD8+ T cells and natural killer cells $[63,64]$. NKTR-214 increases the activation and the PD-L expression of these immune cells [65].

Several studies are currently ongoing in aNSCLC patients, investigating the role of this drug (PROPEL and PIVOT-02 studies).

The PROPEL study is an ongoing phase I/II multicenter study investigating the safety and efficacy of NKTR-214 combined with pembrolizumab in different advanced solid malignancies including aNSCLC. The dose optimization cohort regards the first- and second line, while the dose-expansion cohort includes first-line aNSCLC patients regardless of PD-L1 expression [NCT03138889].

The PIVOT-02 is a four-part study that evaluates the combination of NKTR-214 with nivolumab (part 1), with or without different chemotherapeutic agents (part 2) and with 
nivolumab and ipilimumab (parts 3 and 4). A separate cohort of part 2 will evaluate NKTR214 with nivolumab in aNSCLC patients treated with first-line ICI-CT (NCT02983045) [66] (Table 4).

\section{ICOS Receptor Agonist/Antagonist}

The inducible T cell co-stimulator (ICOS; CD278) belongs to the CD28/CTLA immunoglobulin superfamily and is a positive regulator of T cells [67]. It is weakly expressed on resting Th17 and Treg cells but highly expressed on CD4+ and CD8+ T cells [68-70].

The ICOS agonists/antagonists are studied to overcome resistance to ICIs in monotherapy or combination with other drugs [71].

An ongoing randomized phase II trial is assessing ICOS-agonist antibody (GSK3359609) plus docetaxel versus docetaxel in aNSCLC patients progressing on ICI and CT in the same line or as separate lines of therapy (NCT03739710).

Another phase I/II trial is recruiting untreated and pre-treated aNSCLC patients for an anti-ICOS (KY1044) in combination with atezolizumab (NCT03829501).

\subsubsection{Antiangiogenic Agents}

Receptor tyrosine kinases are known to mediate immunosuppressive mechanisms in TME, and their activation is a potential resistance mechanism to immunotherapy, while their inhibition induces an increase of the anti-tumor immune response [72,73]. This rationale suggests that combining immunotherapy with TKI may result in a re-sensitization to immunotherapy [74-76]. This is an opportunity for beyond progression strategies or for bypassing resistance to immunotherapeutic agents in poorly immunogenic disease sites (e.g., liver metastases) $[77,78]$.

Lenvatinib

Lenvatinib is a multiple TKI that selectively inhibits VEGFR1-3, FGFR1-4, PDGFR $\alpha$, c-KIT, and RET [79]. Lenvatinib has an immune-modulating effect on TME, including the decrease of tumors-associated macrophages (TAMs) and activation of cytotoxic T cells [80]. Therefore, Lenvatinib has shown to be an effective partner in combination with PD-1/PD-L1 inhibitors in different tumors types in both clinical and preclinical studies [73,80].

The ongoing phase III randomized LEAP-008 trial has the aim of assessing the efficacy and safety of pembrolizumab combined with lenvatinib versus docetaxel in nonsquamous aNSCLC patients who failed after platinum-doublet CT and immunotherapy (NCT03976375).

A phase $\mathrm{Ib} / \mathrm{II}$ trial is ongoing on lenvatinib plus pembrolizumab in different tumors and in its phase II part, the cohort including aNSCLC patients experienced promising efficacy results (ORR at 24 weeks of 33\%) (NCT02501096) [81].

Sitravatinib

Sitravatinib is a spectrum-selective TKI including MET, TAM family (Tyro3, AXL, MERTK), VEGFR, PDGFR, KIT and RET [82]. The SAPPHIRE study is an ongoing phase III trial on the combination of sitravatinib and nivolumab versus docetaxel in aNSCLC patients pretreated with ICI and platinum-based CT in combination or sequence (NCT03906071) [83]. Twenty-one (84\%) out of 25 patients experienced tumors reductions and $7(28 \%)$ patients a partial response [83]. 
Table 4. Most relevant ongoing trials investigating different treatment strategies in NSCLC beyond first-line immunotherapy.

\begin{tabular}{|c|c|c|c|c|c|c|c|c|c|}
\hline $\begin{array}{l}\text { N of the } \\
\text { Clinical Trial }\end{array}$ & Phase & Type & Drug & $\operatorname{Arm}(S)$ & $N$ & Patients & Treatment & $\begin{array}{l}\text { Primary } \\
\text { Endpoint }\end{array}$ & $\begin{array}{l}\text { Main Secondary } \\
\text { Endpoints }\end{array}$ \\
\hline NCT02869295 & $\mathrm{I} / \mathrm{II}$ & $\begin{array}{c}\text { Interventional, } \\
\text { non-randomized, } \\
\text { multicenter }\end{array}$ & \multirow[b]{2}{*}{ NKTR-214 } & Single-armed & 40 & $\begin{array}{l}\text { aNSCLC progressed after a maximum of } \\
22 \text { lines. }\end{array}$ & NKTR-214 dose escalation & $\begin{array}{l}\text { Safety } \\
\text { tolerability }\end{array}$ & $\begin{array}{l}\text { ORR; BOR; DOR; PFS; } \\
\text { CBR; MTR; OS; PK; }\end{array}$ \\
\hline NCT03138889 & $\mathrm{I} / \mathrm{II}$ & $\begin{array}{l}\text { Interventional, } \\
\text { non-randomized, } \\
\text { multicenter }\end{array}$ & & Two arms & 135 & First- and second-line aNSCLC. & $\begin{array}{r}\text { NKTR-214 } 0.008 \mathrm{mg} / \mathrm{kg} \text { d1q3w iv } \\
\text { OR } \\
\text { NKTR-214 } 0.006 \mathrm{mg} / \mathrm{kg} \text { d1qq3w iv } \\
+ \\
\text { Pembrolizumab } 200 \mathrm{mg} \text { d1q3w iv }\end{array}$ & $\begin{array}{l}\text { Safety } \\
\text { tolerability } \\
\text { RP2D, } \\
\text { ORR }\end{array}$ & $\begin{array}{c}\text { Safety; Tolerability } \\
\text { ORR; DOR; CBR; TTR; } \\
\text { PFS; OS. }\end{array}$ \\
\hline NCT03739710 & II & $\begin{array}{l}\text { Interventional, } \\
\text { randomized, } \\
\text { multicenter }\end{array}$ & ICOS agonists & Two groups & 105 & $\begin{array}{l}\text { Advanced NSCLC progressed after a } \\
\text { maximum of } 2 \text { lines. Anti-PD-(L1) } \\
\text { and /or platinum-based chemotherapy } \\
\text { (combination or sequence). }\end{array}$ & $\begin{array}{c}\text { GSK3359609 } 80 \mathrm{mg} \text { d1q3w } \\
+ \\
\text { Docetaxel } 75 \mathrm{mg} / \mathrm{m}^{2} \mathrm{~d} 1 \mathrm{q} 3 \mathrm{w} \\
\mathrm{vs} \\
\text { Docetaxel } 75 \mathrm{mg} / \mathrm{m}^{2} \mathrm{~d} 1 \mathrm{q} 3 \mathrm{w}\end{array}$ & OS & $\begin{array}{l}\text { OS; PFS; ORR; DOR; } \\
\text { safety; PK }\end{array}$ \\
\hline NCT03906071 & III & $\begin{array}{l}\text { Interventional, } \\
\text { randomized, } \\
\text { multicenter }\end{array}$ & sitravatinib & Two groups & 532 & $\begin{array}{l}\text { Advanced non-squamous NSCLC } \\
\text { progressed on an anti-PD-(L1) and a } \\
\text { platinum-based chemotherapy } \\
\text { (combination or sequence) }\end{array}$ & $\begin{array}{c}\text { Nivolumab } 240 \mathrm{mg} \text { d1q2 } \mathrm{w} \text { (or } 480 \\
\mathrm{mg} \mathrm{d} 1 \mathrm{q} 4 \mathrm{w} \text { ) iv } \\
+\end{array}$ & OS & ORR; PFS; safety \\
\hline
\end{tabular}


Table 4. Cont.

\begin{tabular}{|c|c|c|c|c|c|c|c|c|c|}
\hline $\begin{array}{l}\mathrm{N} \text { of the } \\
\text { Clinical Trial }\end{array}$ & Phase & Type & Drug & $\operatorname{Arm}(S)$ & $N$ & Patients & Treatment & $\begin{array}{l}\text { Primary } \\
\text { Endpoint }\end{array}$ & $\begin{array}{l}\text { Main Secondary } \\
\text { Endpoints }\end{array}$ \\
\hline NCT03170960 & $\mathrm{I} / \mathrm{II}$ & $\begin{array}{l}\text { Observational } \\
\text { requential } \\
\text { assignment, } \\
\text { multicenter }\end{array}$ & cabozantinib & Three groups & 1732 & $\begin{array}{c}\text { Stage IV non-squamous NSCLC } \\
\text { progressed on or after ICI } \\
\text { Stage IV non-squamous NSCLC } \\
\text { PD-L1-pos in first line } \\
\text { Stage IV non-squamous NSCLC } \\
\text { EGFR-pos progressed on or after TKI }\end{array}$ & $\begin{array}{c}\text { Atezolizumab } 1200 \mathrm{mg} \text { d1q3w iv } \\
+ \\
\text { Cabozantinib } 20-60 \mathrm{mg} \text { once } \\
\text { a day po }\end{array}$ & MTD; ORR & Safety \\
\hline NCT02392455 & $\begin{array}{l}\text { Prospective, } \\
\text { non- } \\
\text { interventional }\end{array}$ & $\begin{array}{l}\text { Observational, } \\
\text { cohort, } \\
\text { multicenter }\end{array}$ & $\begin{array}{l}\text { docetaxel plus } \\
\text { nintedanib }\end{array}$ & Single-armed & 700 & Second-line non-squamous aNSCLC & $\begin{array}{c}\text { Docetaxel } 75 \mathrm{mg} / \mathrm{m}^{2} \mathrm{~d} 1 \mathrm{q} 3 \mathrm{w} \text { iv } \\
+ \\
\text { Nintedanib } 200 \mathrm{mg} \text { bid } \\
\mathrm{d} 2-21 \mathrm{q} 3 \mathrm{w} \text { po }\end{array}$ & $\begin{array}{l}1 \text { year survival } \\
\text { rate }\end{array}$ & $\begin{array}{l}\text { 1-year survival rate and } \\
\text { PFS of patients with first } \\
\text { line PD within } 9 \text { months; } \\
\text { mOS; PFS, DCR; safety }\end{array}$ \\
\hline NCT02817633 & I & $\begin{array}{l}\text { Interventional, } \\
\text { non-randomized, } \\
\text { multicenter }\end{array}$ & $\begin{array}{c}\text { TSR-022 } \\
\text { (anti-TIM-3) } \\
\text { TSR-042 } \\
\text { (anti-PD-1) } \\
\text { TSR-033 } \\
\text { (anti-LAG-3) }\end{array}$ & $\begin{array}{l}\text { Thirteen } \\
\text { groups }\end{array}$ & 369 & Non-squamous aNSCLC & $\begin{array}{c}\text { TSR-022 } \\
\text { OR } \\
\text { TSR-022 + nivolumab } \\
\text { OR } \\
\text { TSR-022 + TSR-042 } \\
\text { OR } \\
\text { TSR-022 + TSR-042 + TSR-033 } \\
\text { OR } \\
\text { TSR-022 + TSR-042 } \\
\text { OR } \\
\text { TSR-022 + TSR-042 + Docetaxel }\end{array}$ & $\begin{array}{l}\text { DLT, SAEs, } \\
\text { TEAEs, irAEs, } \\
\text { ORR }\end{array}$ & $\begin{array}{l}\text { ORR, DOR, PFS, OS, PK, } \\
\text { anti-TSR-022, } \\
\text { anti-TSR-042 } \\
\text { anti-TSR-033 }\end{array}$ \\
\hline NCT02608268 & I - I b/II & $\begin{array}{l}\text { Interventional, } \\
\text { non-randomized, } \\
\text { multicenter }\end{array}$ & $\begin{array}{l}\text { MBG453 } \\
\text { (anti-TIM-3) } \\
\text { PDR001 } \\
\text { (anti-PD-1) }\end{array}$ & Six groups & 252 & aNSCLC & $\begin{array}{c}\text { MBG453 } \\
\text { OR } \\
\text { MBG453 + PDR001 } \\
\text { OR } \\
\text { MBG453 + decitabine }\end{array}$ & $\begin{array}{l}\text { Safety, } \\
\text { tolerability, } \\
\text { ORR, DLT }\end{array}$ & $\begin{array}{l}\text { BOR, OS, DOR, PFS, } \\
\text { ORR, PK, expression of } \\
\text { PDL-1, PDp }\end{array}$ \\
\hline NCT03708328 & I & $\begin{array}{l}\text { Interventional, } \\
\text { non-randomized, } \\
\text { multicenter }\end{array}$ & $\begin{array}{l}\text { RO7121661 } \\
\text { (anti-PD-1 and } \\
\text { anti-TIM-3) }\end{array}$ & Single arm & 280 & $\begin{array}{l}\text { aNSCLC in first-line ICI-naive or in } \\
\text { second/ third-line (PD-L1 positive). SCLC }\end{array}$ & RO7121661 & $\begin{array}{l}\text { AEs, DLT, } \\
\text { ORR, DCR, } \\
\text { DOR, PFS. }\end{array}$ & $\begin{array}{l}\text { PK, anti-drug antibodies, } \\
\text { ORR, PDp }\end{array}$ \\
\hline NCT04154956 & III & $\begin{array}{l}\text { Interventional, } \\
\text { randomized, } \\
\text { multicenter }\end{array}$ & $\begin{array}{c}\text { SAR408701 } \\
\text { (anti-CEACAM5 } \\
\text { plus mayatasinoid } \\
\text { DM4) }\end{array}$ & Two arms & 554 & $\begin{array}{l}\text { Stage IV non-squamous NSCLC } \\
\text { progressed on anti-PD-(L1) and } \\
\text { platinum-based chemotherapy, } \\
\text { with CEACAM5 expression }\end{array}$ & $\begin{array}{c}\text { SAR408701 } 100 \mathrm{mg} / \mathrm{m}^{2} \mathrm{~d} 1 \mathrm{q} 2 \mathrm{w} \text { iv } \\
\text { vs. } \\
\text { Docetaxel } 75 \mathrm{mg} / \mathrm{m}^{2} \mathrm{~d} 1 \mathrm{q} 3 \mathrm{w} \text { iv }\end{array}$ & PFS, OS & $\begin{array}{l}\text { ORR, QoL, DOR, } \\
\text { TEAEs, SAEs }\end{array}$ \\
\hline
\end{tabular}

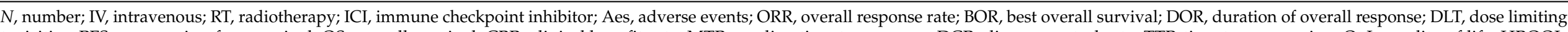

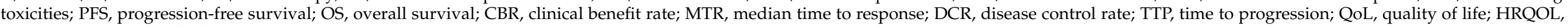

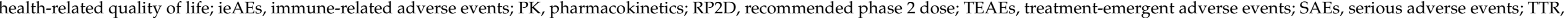
time to response; PDp, pharmacodynamic parameters. 


\section{Cabozantinib}

Cabozantinib is a potent inhibitor of multiple receptor tyrosine kinases, including MET, VEGFR, AXL and RET [84]. Preclinical studies showed that cabozantinib promotes an immune-permissive TME through the inhibition of immune-suppressive cells and tumors neovascularization $[74,75,85]$.

It has been observed to overcome immunotherapy resistance by the resensitization to ICIs in several clinical studies and different types of tumors [86,87]. A phase $\mathrm{Ib} / \mathrm{II}$ trial is ongoing on cabozantinib and atezolizumab as monotherapy or in combination as first- or further-lines in patients with multiple tumors types, including aNSCLC (NCT03170960). Finally, CONTACT-01, the ongoing phase III trial will evaluate the association of cabozantinib+atezo versus docetaxel in NSCLC pretreated with CHT and ICI (NCT04471428).

\subsubsection{Combination of Immunotherapeutic Agents}

Nivolumab plus Ipilimumab

Nivolumab, an anti-PD-1 antibody, and ipilimumab, an anti-CTLA-4 antibody, modulate effector $\mathrm{T}$ cell activation, proliferation, and function with distinct but complementary mechanisms [88]. Their combination has proved to be effective in aNSCLC, melanoma and renal cell carcinoma [89-92].

An ongoing phase II trial is evaluating if the addition of ipilimumab to nivolumab after primary resistance to anti-PD1 therapy can lead to tumor reduction. The investigators will primarily enroll aNSCLC patients who have experienced progression or stable disease less than 24 weeks as best clinical response to anti-PD-1 monotherapy (primary resistance). A smaller cohort of patients with stable disease for at least 24 weeks, partial/complete response as the best clinical response to anti-PD-1 monotherapy, with subsequent progression (acquired resistance), will additionally be accrued (NCT03262779).

\subsection{Strategies beyond Immunotherapy}

The therapeutic strategies with the interruption of immunotherapy include the use of (1) CT in combination with antiangiogenetics, (2) CT alone and (3) the use of new TKIs.

\subsubsection{Antiangiogenetics plus Chemotherapy}

The efficacy of the association of antiangiogenetics and CT is well-known in aNSCLC patients, such as the combination of bevacizumab with $\mathrm{CT}$ and immunotherapy as firstline therapy in the IMpower150 trial or the association of bevacizumab plus paclitaxel or nintedanib plus docetaxel in pretreated non-squamous NSCLC patients [93-95]. Moreover, antiangiogenetics have an immune effect similarly to TKIs, so their combination with immunotherapy has been investigated a different type of tumors [96,97].

The VARGADO trial is an ongoing observational prospective study that evaluates the combination of docetaxel plus nintedanib as second line after first-line CT or ICI-CT or as third line after first-line CT and second-line ICI [NCT02392455]. Grohè et al. [98] reported the results of the clinical benefit of nintedanib plus docetaxel after ICI therapy progression, according to PFS, ORR, and DCR (5.5 months, 58\% and $83 \%$ respectively). This result highlighted the potential clinical benefit of treatment sequencing with antiangiogenics and chemotherapy after immunotherapy [99].

\subsubsection{Chemotherapy}

The stimulating effect of $\mathrm{CT}$ on the immune system is well-known including immunogenic cell death with the release of tumors antigens in the TME, inhibition of tumors neovascularization and modulation of the immunogenicity of tumor cells by enhancing antigen presentation, upregulating expression of costimulatory molecules or downregulating inhibitory checkpoint molecules [100-102].

Chemotherapy and immunotherapy are known to have synergistic effects and ICI may enhance CT efficacy when delivered before the cytotoxic agent in NSCLC patients $[41,103]$. 
In the KEYNOTE-024 study, which randomized aNSCLC patients with PD-L1 $\geq 50 \%$ into first-line CT or pembrolizumab, cross-over was permitted on disease progression and this allows to assess the combination of the PFS for the first- and second-line therapy (PFS2) between the two arms [104]. A recent analysis showed that the PFS2 for first-line pembrolizumab plus second-line CT was significantly longer than that of first-line CT plus second-line pembrolizumab [105].

This result could lead to the hypothesis that the sooner immunotherapy is given the more efficacy will be reached and CT seems to be a valid salvage therapy after immunotherapy failure.

To date, in clinical practice, patients who progress upon immunotherapy received $\mathrm{CT}$ including platinum-based doublet, if not previously given, or docetaxel \pm ramucirumab/nintedanib, gemcitabine, and pemetrexed [106,107].

The role of $\mathrm{CT}$ as salvage therapy after first-line immunotherapy is currently being investigated in an ongoing trial to assess the addition of CT to immunotherapy in patients who progressed upon PD-1/PD-L1 inhibitor [NCT03083808].

\subsubsection{New Targeted Therapies KRAS Inhibitors}

The KRAS ${ }^{G 12 C}$ mutation is found in approximately $13 \%$ of lung adenocarcinomas and several ongoing trials are assessing the safety and activity of KRAS inhibitors in KRAS ${ }^{G 12 C}$-mutant patients with different types of tumors. These include also aNSCLC which progressed after standard treatment including chemotherapy and immunotherapy [108].

A phase I/II study evaluating AMG510 (Sotorasib) in pretreated patients with KRAS G12C-mutated solid tumors showed a favorable safety profile and interesting antitumor activity. The phase II cohort has now shown a durable response rate of $37.1 \%$, a disease control rate of $80.6 \%$, and a median progression-free survival of 6.8 months (NCT03600883) [109,110]. Recently, a randomized phase III study comparing AMG510 with docetaxel in 650 NSCLC patients has been activated (NCT04303780). If the results will be confirmed, it will be the registration trial. This randomized clinical trial aims to enroll around 325 patients per arm: AMG510 with docetaxel in NSCLC.

The phase II Lung-MAP trial is currently ongoing (NCT04625647). The other two KRAS inhibitors, MRTX849 and JNJ74699157, are currently under investigation in two phase I-II trials in patients with advanced KRAS ${ }^{G 12 C}$ mutant solid tumors (NCT03785249, NCT04006301).

\section{PARP-Inhibitors}

PARP-inhibitors are oral small molecule inhibitors of poly (ADP-ribose) polymerase (PARP) enzymes which have a role in cellular growth, regulation, and cell repair from DNA damage. In this way, PARP inhibitors stop cancer cells from being repaired which causes the death of tumors cells [111]. The inhibition of DNA damage repair and the subsequent cell death increase tumors antigens release enhancing the immune response, supporting the rationale of combining PARP-inhibitors and ICIs [111,112].

There are many ongoing phase II-III studies that combine a PARP-inhibitor (e.g., olaparib) with an anti-PD1/PD-L1 (e.g., pembrolizumab) as maintenance therapy after the first line in aNSCLC patients [113] (NCT03976323, NCT03775486).

\subsection{Multiple Strategies and Innovative Trials}

Different trials are assessing different anticancer therapies in aNSCLC patients pretreated with immunotherapy.

The HUDSON trial is an ongoing phase II umbrella study that enrols aNSCLC patients who progressed after a platinum-based CT and an anti-PD-1/PD-L1 therapy, as monotherapy or in combinations. Different drugs with different mechanisms of action are assessed in combination with durvalumab including olaparib, AZD9150 (JAK-STAT3 pathwayinhibitor), ceralasertib (ATR kinase inhibitor), vistusertib (mTOR inhibitor), oleclumab (anti- 
CD73), trastuzumab-deruxtecan (antibody-drug conjugate) and cediranib (anti-VEGFR-1-3) [NCT03334617] [114].

In the phase I/II CheckMate 79X study, aNSCLC patients who progressed on ICIs and CT (given either concurrently or sequentially) are randomized to docetaxel versus different nivolumab-containing combinations including nivolumab (plus ipilimumab) plus cabozantinib, docetaxel plus ramucirumab, docetaxel and lucitanib, which is a VEGFR-1-3 and FGFR-1-2 inhibitor [NCT04151563].

In recent years, the CAR-T cells immunotherapy, consisting in patient's T cells genetically engineered to produce an artificial T-cell receptor, has reported great results in many malignancies, especially in hematologic ones [115]. In aNSCLC patients, several trials are ongoing evaluating the safety and activity of CAR-T cells in different treatment settings [NCT03525782, NCT02587689].

Other co-inhibitory receptors and cell surface ligands are under investigation including $\mathrm{T}$ cell immunoglobulin and mucin domain 3 (Tim-3), lymphocyte-activation gene 3 (LAG-3), and Carcinoembryonic Antigen-related Cell Adhesion Molecule 5 (CEACAM5).

$\mathrm{T}$ cell immunoglobulin and mucin domain 3 is a co-inhibitory receptor particularly expressed on exhausted CD8+ T cells and in preclinical models the co-block of $\mathrm{PD}(\mathrm{L})-1$ and Tim-3 receptors has shown to be effective in solid tumors [116]. Furthermore, Tim-3 deregulation has been associated with the development of resistance to $\mathrm{PD}(\mathrm{L})-1$ inhibition in NSCLC patients [117]. Many phase I/II studies are investigating the efficacy of Tim-3 antagonists in association with anti-PD(L)-1. Preliminary data of the phase I AMBER study on the combination of TSR-022 (anti-TIM-3 monoclonal antibody), and TSR-042 (antiPD-1 inhibitor) showed promising clinical activity and good safety in aNSCLC patients progressed on anti-PD(L)-1 treatment (NCT02817633) [116,118].

Another ongoing phase I/II trial evaluates the safety and activity of MBG453 (Tim-3 inhibitor) with or without PDR001 (anti-PD-1, spartalizumab) in patients with advanced solid tumors, including aNSCLC patients, pretreated or not with an anti-PD(L)-1 therapy (NCT02608268). The phase II cohort on aNSCLC patients progressed upon anti-PD-(L)1 therapy receiving MBG453 + PDR001 showed good tolerance but limited efficacy [119].

A bispecific antibody inhibiting both Tim-3 and PD-1 (RO7121661) is currently studied in a phase I study in patients with advanced solid tumors including aNSCLC (NCT03708328).

Lymphocyte-activation gene 3 is expressed on activated CD4+ and CD8+ T cells, Treg and other immune cells. Similar to CD4, Lag-3 binds MHC class II, but with a higher affinity, with the subsequent reduction of $\mathrm{T}$ cell proliferation and lower pro-immune cytokine production [120]. There are many ongoing phase I/II trials evaluating the safety and the activity of LAG-3 inhibitors as monotherapy or in association with anti-PD(L)-1 in many advanced tumors, including aNSCLC pretreated with immunotherapy [NCT 02460224, NCT01968109, NCT02913313]. Furthermore, also for LAG-3, there is an anti-PD1-LAG-3 bispecific antibody that is currently under evaluation in a phase I trial on patients with advanced solid tumors, including aNSCLC patients previously treated with PD-(L)1 inhibitor (NCT04140500).

CEACAM5 is a surface protein on tumors cells involved in cancer invasion and metastatization [121]. SAR408701 is an antibody-drug conjugate that consists of antiCEACAM5 antibody conjugated to a cytotoxic agent maytansinoid DM4. The CARMANLC03 trial is an ongoing phase III trial on SAR408701 versus docetaxel in pretreated CEACAM5+ aNSCLC patients progressing after CT and ICIs [NCT04154956].

For more advanced immunotherapeutic agents (oncolytic viruses, vaccines, other cellular therapy) we suggest referring to dedicated reviews and make a constant bring up to date on dedicated software (e.g., ClinicalTrials.gov (accessed on 6 February 2021), PubMed).

\section{Treatment Strategies for Late Systemic Progression}

Long-responders to immunotherapy should be divided according to the timing of progression in those who progress after interruption of prior immunotherapy and those who progress during immunotherapy. Patients who progress after a therapeutic interval from 
immunotherapy in monotherapy or combination may benefit from treatment rechallenge of the interrupted therapy.

\subsection{Rechallenge of Immunotherapy after Immunotherapy}

The rechallenge of ICIs could be defined as a second course of treatment after an interval of almost 3 months. This because, regardless of the dose, the half-life of most antiPD-(L) 1 antibodies ranges between 12 and 20 days and the occupancy of PD-1 molecules on circulating $\mathrm{T}$ cells remains for almost 3 months [122]. The ICI rechallenge is a promising treatment approach, especially in advanced melanoma patients [123-125].

To date, three prospective clinical trials reported the efficacy and safety of ICIs rechallenge in aNSCLC patients. The CheckMate 153 investigated the survival benefit of a fixed-duration (1 year) vs. continuous treatment of nivolumab as second-line therapy in aNSCLC patients. In the fixed-duration arm, 47 patients progressed during the follow-up period and 39 patients $(83 \%)$ were retreated with the same therapy [126]. The median duration of nivolumab retreatment was 3.8 months and disease progression on target lesions and new lesions were reported in $35 \%$ and $41 \%$ of cases, respectively [126].

In the phase II/III KEYNOTE-010 trial on pembrolizumab versus docetaxel in pretreated aNSCLC patients with PD-L1 $\geq 1 \%$, after 2 years of pembrolizumab 25 (32\%) patients progressed and $14(56 \%)$ were rechallenged with a second course of pembrolizumab, reporting partial response and stable disease in $43 \%$ and $36 \%$ of patients, respectively, with a disease control rate of $79 \%[127,128]$.

In addition, in the first-line setting, KEYNOTE-024 trial reported a disease control rate of $70 \%$ in untreated patients with PD-L1 $\geq 50 \%$ receiving retreatment with pembrolizumab after the completion of 2 years of pembrolizumab [129].

Rechallenge in real life has been recently published in a national database analysis on 10,452 sNSCLC patients treated with nivolumab. About half of the patients received post-nivolumab therapy lines and among them, 1517 patients (about 30\%) received a second course of PD-1 inhibitors, either after a treatment-free interval (resumption group, $N=1127$ ), or after chemotherapy (rechallenge group, $N=390$ ). The mOS was 15.0 and 18.4 months in the resumption and rechallenge group respectively and, regardless of the group, it was longer in patients initially receiving nivolumab for $\geq 3$ months [130].

A phase II clinical trial is assessing rechallenge with pembrolizumab as second or further-line in aNSCLC patients progressing on anti-PDL1 drug. This trial consists of two treatment groups depending on when the progression disease occurred: cohort 1 consists of patients progressing during treatment or $<12$ weeks after stopping it, then received $\mathrm{CT} \geq 4$ cycles and progressed again; cohort 2 consists of patients who stopped treatment and progressed after $\geq 12$ weeks (NCT03526887).

According to these data, in aNSCLC patients experiencing a long-term benefit from ICI, the rechallenge of immunotherapy can be considered as a therapeutic option, especially in case of a lack of valid therapeutic alternatives. However, available literature data are not sufficient to give clear recommendations and more prospective trial are needed.

\subsection{Rechallenge of Chemotherapy after Immuno-Chemotherapy}

Rechallenge with CT may be attempted if the disease has initially responded to it and is recommended in many tumors whenever there are no valid treatment alternatives [131].

Several phase II studies investigated the clinical benefit of platinum-based CT in patients previously treated with it with conflicting results $[132,133]$. The pooled-analysis conducted by Petrelli et al. [132] on 11 studies showed that rechallenge with platinumbased CT was associated with an interesting tumor response rate of $27 \%$ but with no survival advantage compared to conventional second-line agents.

The availability of different effective drugs and the potential cumulative platinumrelated hematological (neutropenia, anemia, thrombocytopenia) and non-hematological toxicities (renal damage, ototoxicity, neurological toxicity, etc.) makes the platinum-based $\mathrm{CT}$ rechallenge an unusual strategy in clinical practice. 
However, retreatment with platinum-based CT could be hypothetically proposed for patients treated with first-line ICI-CT who are still in treatment with immunotherapy and with a long time to progression from the last CT.

A prospective trial should be conducted to definitively address if platinum-based CT rechallenge after ICT-CT could represent an option for relapsed platinum-sensitive patients.

\section{Conclusions}

Identifying effective treatment strategies for NSCLC patients who have progressed upon single-agent ICI or ICI-based combinations is an unmet clinical need and an important issue of clinical research.

Many ongoing studies are investigating different approaches to overcome the different resistance mechanisms in both oligoprogressive and systemic progressive ICI patients, therefore enrollment in clinical trials is recommended.

New LAT methods and drug combinations could overcome resistances in oligo PD during immunotherapy.

In systemic PD, a new challenge is to estimate the type of resistance by reasoning about the timing of PD and, if possible, by performing a new biopsy (Figure 1).

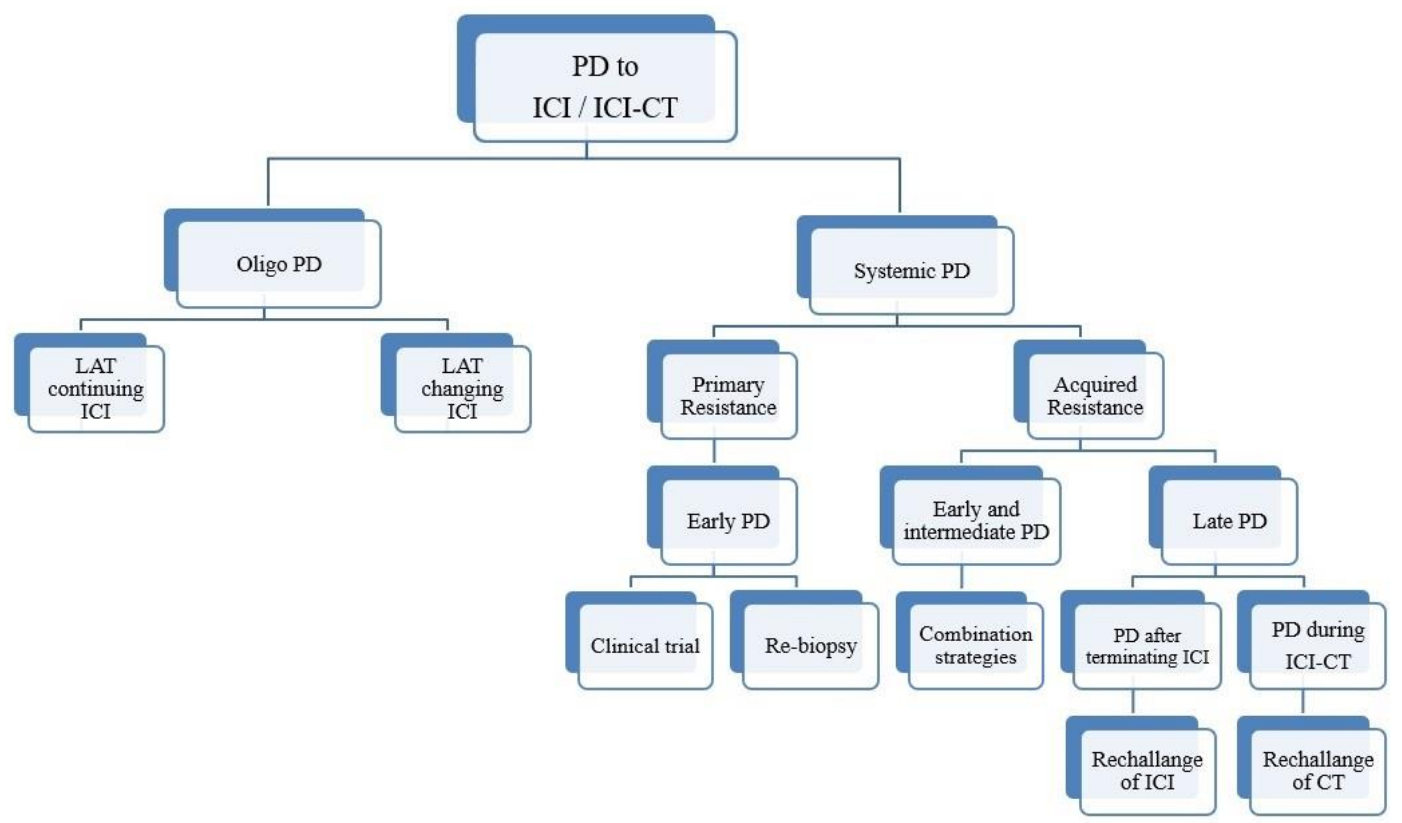

Figure 1. Schematic representation of an algorithm for patients with NSCLC who progressed upon IO-based therapy.

Funding: No funding was received.

Conflicts of Interest: M.C.G. declares personal financial interests with the following organizations: AstraZeneca, MSD International GmbH, BMS, Boehringer Ingelheim Italia S.p.A, Celgene, Eli Lilly, Ignyta, Incyte, Inivata, MedImmune, Novartis, Pfizer, Roche, Takeda. F.d.B. declares: Consultant Advisory Board for Ignyta, BMS, Daiichi Sankyo, Pfizer, Octimet Oncology, Incyte, Teofarma, Pierre Fabre, Roche, EMD Serono, Sanofi, NMS Nerviano Medical Science, Pharm Research Associated (U.K) Ltd.; as a Speaker BMS, Roche, MSD, Ignyta, Bayer, ACCMED, Dephaforum S.r.l., Nadirex, Merck, Biotechspert Ltd., PriME Oncology, Pfizer, Servier, Celgene, Tesaro, Loxo Oncology Inc., Sanofi, Healthcare Research \& Pharmacoepidemiology, as P.I for Novartis, Roche, BMS, Celgene, Incyte, NMS, Merck KGAA, Kymab, Pfizer, Tesaro, MSD. A.P. declares personal fees from Roche, AstraZeneca and BMS outside the submitted work. C.P. declares personal fees from BMS and MSD, outside the submitted work. G.L.R. declares personal fees from BMS, MSD and Astra Zeneca outside the submitted work. B.A.J.-F. declares personal fees from Janssen, Ferring, Bayer, Roche, Astellas, Elekta, Carl Zeiss, Ipsen, Accurary, IBA. Deaclears grant from: Accurary, AIRC and FIEO-CCM and FUV. C.G. declares personal fees from Roche, AstraZeneca, BMS, MS. 


\section{References}

1. Saxena, P.; Singh, P.K.; Malik, P.S.; Singh, N. Immunotherapy Alone or in Combination with Chemotherapy as First-Line Treatment of Non-Small Cell Lung Cancer. Curr. Treat. Options Oncol. 2020, 21, 1-21. [CrossRef]

2. Planchard, D.; Popat, S.; Kerr, K.; Novello, S.; Smit, E.F.; Faivre-Finn, C.; Mok, T.S.; Reck, M.; Van Schil, P.E.; Hellmann, M.D.; et al. Clinical Practice Guidelines-Metastatic Non-Small Cell Lung Cancer: ESMO Clinical Practice Guidelines for Diagnosis, Treatment and Follow-Up. Available online: https://www.esmo.org/guidelines/lung-and-chest-tumours/clinical-practice-livingguidelines-metastatic-non-small-cell-lung-cancer (accessed on 6 February 2021).

3. Heigener, D.F.; Kerr, K.M.; Laing, G.M.; Mok, T.S.; Moiseyenko, F.V.; Reck, M. Redefining Treatment Paradigms in First-line Advanced Non-Small-Cell Lung Cancer. Clin. Cancer Res. 2019, 25, 4881-4887. [CrossRef]

4. Low, J.L.; Walsh, R.J.; Ang, Y.; Chan, G.; Soo, R.A. The evolving immuno-oncology landscape in advanced lung cancer: First-line treatment of non-small cell lung cancer. Ther. Adv. Med Oncol. 2019, 11, 1758835919870360. [CrossRef]

5. Franceschini, D.; De Rose, F.; Cozzi, S.; Franzese, C.; Rossi, S.; Finocchiaro, G.; Toschi, L.; Santoro, A.; Scorsetti, M. The use of radiation therapy for oligoprogressive/oligopersistent oncogene-driven non small cell lung cancer: State of the art. Crit. Rev. Oncol. 2020, 148, 102894. [CrossRef]

6. Hellman, S.; Weichselbaum, R.R. Oligometastases. J. Clin. Oncol. 1995, 13, 8-10. [CrossRef]

7. Guckenberger, M.; Lievens, Y.; Bouma, A.B.; Collette, L.; Dekker, A.; Desouza, N.M.; Dingemans, A.-M.C.; Fournier, B.; Hurkmans, C.; Lecouvet, F.; et al. Characterisation and classification of oligometastatic disease: A European Society for Radiotherapy and Oncology and European Organisation for Research and Treatment of Cancer consensus recommendation. Lancet Oncol. 2020, 21, e18-e28. [CrossRef]

8. $\quad$ Lieverse, R.I.Y.; Van Limbergen, E.J.; Oberije, C.J.G.; Troost, E.G.C.; Hadrup, S.R.; Dingemans, A.-M.C.; Hendriks, L.E.L.; Eckert, F.; Hiley, C.; Dooms, C.; et al. Stereotactic ablative body radiotherapy (SABR) combined with immunotherapy (L19-IL2) versus standard of care in stage IV NSCLC patients, ImmunoSABR: A multicentre, randomised controlled open-label phase II trial. BMC Cancer 2020, 20, 557. [CrossRef] [PubMed]

9. NCCN Clinical Practice Guidelines in Oncology (NCCN Guidelines)-Non-Small Cell Lung Cancer (Version 1.2021). Available online: https:/ /www.nccn.org/professionals/physician_gls/pdf/nscl_blocks.pdf (accessed on 6 February 2021).

10. Jairam, V.; Park, H.S.; Decker, R.H. Local Ablative Therapies for Oligometastatic and Oligoprogressive Non-Small Cell Lung Cancer. Cancer J. 2020, 26, 129-136. [CrossRef] [PubMed]

11. Laurie, S.A.; Banerji, S.; Blais, N.; Brule, S.; Cheema, P.K.; Cheung, P.; Daaboul, N.; Hao, D.; Hirsh, V.; Juergens, R.; et al. Canadian Consensus: Oligoprogressive, Pseudoprogressive, and Oligometastatic Non-Small-Cell Lung Cancer. Curr. Oncol. 2019, $26,81-93$. [CrossRef]

12. Conforti, F.; Catania, C.; Toffalorio, F.; Duca, M.; Spitaleri, G.; Barberis, M.; Noberasco, C.; Delmonte, A.; Santarpia, M.; Lazzari, C.; et al. EGFR tyrosine kinase inhibitors beyond focal progression obtain a prolonged disease control in patients with advanced adenocarcinoma of the lung. Lung Cancer 2013, 81, 440-444. [CrossRef]

13. Rheinheimer, S.; Heussel, C.-P.; Mayer, P.; Gaissmaier, L.; Bozorgmehr, F.; Winter, H.; Herth, F.J.; Muley, T.; Liersch, S.; Bischoff, H.; et al. Oligoprogressive Non-Small-Cell Lung Cancer under Treatment with PD-(L)1 Inhibitors. Cancers 2020, $12,1046$. [CrossRef]

14. Couñago, F.; Luna, J.; Guerrero, L.L.; Vaquero, B.; Guillén-Sacoto, M.C.; González-Merino, T.; Taboada, B.; Díaz, V.; Rubio-Viqueira, B.; Díaz-Gavela, A.A.; et al. Management of oligometastatic non-small cell lung cancer patients: Current controversies and future directions. World J. Clin. Oncol. 2019, 10, 318-339. [CrossRef]

15. Schanne, D.H.; Heitmann, J.; Guckenberger, M.; Andratschke, N.H. Evolution of treatment strategies for oligometastatic NSCLC patients-A systematic review of the literature. Cancer Treat. Rev. 2019, 80, 101892. [CrossRef]

16. Theelen, W.S.; de Jong, M.C.; Baas, P. Synergizing systemic responses by combining immunotherapy with radiotherapy in metastatic non-small cell lung cancer: The potential of the abscopal effect. Lung Cancer 2020, 142, 106-113. [CrossRef]

17. Zhuang, H. Abscopal effect of stereotactic radiotherapy combined with anti-PD-1/PD-L1 immunotherapy: Mechanisms, clinical efficacy, and issues. Cancer Commun. 2020, 40, 649-654. [CrossRef]

18. Kim, C.; Hoang, C.D.; Kesarwala, A.H.; Schrump, D.S.; Guha, U.; Rajan, A. Role of Local Ablative Therapy in Patients with Oligometastatic and Oligoprogressive Non-Small Cell Lung Cancer. J. Thorac. Oncol. 2017, 12, 179-193. [CrossRef]

19. Griswold, C.R.; Kerrigan, K.; Patel, S.B. Combination of Local Ablative Therapy and Continuation of Immune Checkpoint Inhibitor (ICI) Therapy Provides Durable Treatment Response Past Oligometastatic Progression in NSCLC: A Case Report. Case Rep. Oncol. 2019, 12, 866-871. [CrossRef]

20. Sotelo, M.; Cabezas-Camarero, S.; Riquelme, A.; Bueno, C. Long-term survival of a patient with programmed death ligand 1-negative lung adenocarcinoma and oligoprogressive disease treated with nivolumab and stereotactic body radiation therapy. J. Cancer Res. Ther. 2020, 16, 941. [CrossRef]

21. Tobita, S.; Kinehara, Y.; Tamura, Y.; Kurebe, H.; Ninomiya, R.; Utsu, Y.; Kohmo, S.; Sato, B.; Nagai, K.; Maruoka, S.; et al. Successful continuous nivolumab therapy for metastatic non-small cell lung cancer after local treatment of oligometastatic lesions. Thorac. Cancer 2020, 11, 2357-2360. [CrossRef]

22. Bledsoe, T.; Rutter, C.; Lester-Coll, N.; Bi, X.; Decker, R. Radiation to Oligoprogessive Sites of Disease Can Prolong the Duration of Response to Immune Checkpoint Inhibitors in Patients with Metastatic Non-Small Cell Lung Cancer. Int. J. Radiat. Oncol. 2016, 96, E479. [CrossRef] 
23. Mersiades, A.; Crumbaker, M.; Gao, B.; Nagrial, A.; Hui, R. P3.02c-033 Patterns of Progression and Management of Acquired Resistance to Anti-PD-1 Antibodies in Advanced Non-Small Cell Lung Cancer. J. Thorac. Oncol. 2017, 12, S1293. [CrossRef]

24. Gettinger, S.N.; Wurtz, A.; Goldberg, S.B.; Rimm, D.; Schalper, K.; Kaech, S.; Kavathas, P.; Chiang, A.; Lilenbaum, R.; Zelterman, D.; et al. Clinical Features and Management of Acquired Resistance to PD-1 Axis Inhibitors in 26 Patients With Advanced Non-Small Cell Lung Cancer. J. Thorac. Oncol. 2018, 13, 831-839. [CrossRef] [PubMed]

25. Guisier, F.; Gervais, R.; El Husseini, K.; Assié, J.-B.; Geier, M.; Decroisette, C.; Corre, R.; Descourt, R.; Chouaid, C.; Salaun, M.; et al. Local ablative treatment and treatment beyond progression for oligo-progression in stage IV non-small cell lung cancer after tumour response to anti-PD1 treatment. Ann. Oncol. 2019, 30, v620-v621. [CrossRef]

26. Metro, G.; Addeo, A.; Signorelli, D.; Gili, A.; Economopoulou, P.; Roila, F.; Banna, G.; De Toma, A.; Cobo, J.R.; Camerini, A.; et al. Outcomes from salvage chemotherapy or pembrolizumab beyond progression with or without local ablative therapies for advanced non-small cell lung cancers with PD-L1 $\geq 50 \%$ who progress on first-line immunotherapy: Real-world data from a European cohort. J. Thorac. Dis. 2019, 11, 4972-4981. [CrossRef] [PubMed]

27. Kroeze, S.; Fritz, C.; Kaul, D.; Blanck, O.; Kahl, K.; Roeder, F.; Siva, S.; Verhoeff, J.; Grosu, A.; Schymalla, M.; et al. Stereotactic radiotherapy concurrent to immune or targeted therapy for oligometastatic NSCLC: Clinical scenarios affecting survival. Ann. Oncol. 2019, 30, ii63. [CrossRef]

28. Sharma, P.; Hu-Lieskovan, S.; Wargo, J.A.; Ribas, A. Primary, Adaptive, and Acquired Resistance to Cancer Immunotherapy. Cell 2017, 168, 707-723. [CrossRef]

29. Sucker, A.; Zhao, F.; Real, B.; Heeke, C.; Bielefeld, N.; Maßen, S.; Horn, S.; Moll, I.; Maltaner, R.; Horn, P.A.; et al. Genetic Evolution of T-cell Resistance in the Course of Melanoma Progression. Clin. Cancer Res. 2014, 20, 6593-6604. [CrossRef]

30. Marincola, F.M.; Jaffee, E.M.; Hicklin, D.J.; Ferrone, S. Escape of human solid tumourss from T-cell recognition: Molecular mechanisms and functional significance. Adv. Immunol. 2000, 74, 181-273. [CrossRef] [PubMed]

31. D'Urso, C.M.; Wang, Z.G.; Cao, Y.; Tatake, R.; Zeff, R.; Ferrone, S. Lack of HLA class I antigen expression by cultured melanoma cells FO-1 due to a defect in B2m gene expression. J. Clin. Investig. 1991, 87, 284-292. [CrossRef] [PubMed]

32. Bradley, S.D.; Chen, Z.; Melendez, B.; Talukder, A.; Khalili, J.S.; Rodriguez-Cruz, T.; Liu, S.; Whittington, M.; Deng, W.; Li, F.; et al. BRAFV600E Co-opts a Conserved MHC Class I Internalization Pathway to Diminish Antigen Presentation and CD8+ T-cell Recognition of Melanoma. Cancer Immunol. Res. 2015, 3, 602-609. [CrossRef]

33. Kim, H.-J.; Bae, S.-C. Histone deacetylase inhibitors: Molecular mechanisms of action and clinical trials as anti-cancer drugs. Am. J. Transl. Res. 2011, 3, 166-179. [PubMed]

34. Karpf, A.R.; Jones, D.A. Reactivating the expression of methylation silenced genes in human cancer. Oncogene 2002, 21, 5496-5503. [CrossRef]

35. D'Souza, W.N.; Chang, C.-F.; Fischer, A.M.; Li, M.; Hedrick, S.M. The Erk2 MAPK Regulates CD8 T Cell Proliferation and Survival. J. Immunol. 2008, 181, 7617-7629. [CrossRef]

36. Peng, W.; Chen, J.Q.; Liu, C.; Malu, S.; Creasy, C.; Tetzlaff, M.T.; Xu, C.; McKenzie, J.A.; Zhang, C.; Liang, X.; et al. Loss of PTEN Promotes Resistance to T Cell-Mediated Immunotherapy. Cancer Discov. 2016, 6, 202-216. [CrossRef]

37. Kaneda, M.M.; Messer, K.S.; Ralainirina, N.; Li, H.; Leem, C.J.; Gorjestani, S.; Woo, G.; Nguyen, A.V.; Figueiredo, C.C.; Foubert, P.; et al. PI3K $\gamma$ is a molecular switch that controls immune suppression. Nature 2016, 539, 437-442. [CrossRef]

38. De Henau, O.; Rausch, M.; Winkler, D.; Campesato, L.F.; Liu, C.; Cymerman, D.H.; Budhu, S.; Ghosh, A.; Pink, M.; Tchaicha, J.; et al. Overcoming resistance to checkpoint blockade therapy by targeting PI3K $\gamma$ in myeloid cells. Nat. Cell Biol. 2016, 539, 443-447. [CrossRef]

39. Spranger, S.; Bao, R.; Gajewski, T.F. Melanoma-intrinsic $\beta$-catenin signalling prevents anti-tumour immunity. Nat. Cell Biol. 2015, 523, 231-235. [CrossRef]

40. Gao, J.; Shi, L.Z.; Zhao, H.; Chen, J.; Xiong, L.; He, Q.; Chen, T.; Roszik, J.; Bernatchez, C.; Woodman, S.E.; et al. Loss of IFN- $\gamma$ Pathway Genes in Tumor Cells as a Mechanism of Resistance to Anti-CTLA-4 Therapy. Cell 2016, 167, 397-404.e9. [CrossRef]

41. Park, S.E.; Ee, P.S.; Ahn, J.S.; Ahn, M.-J.; Park, K.; Sun, J.-M. Increased Response Rates to Salvage Chemotherapy Administered after PD-1/PD-L1 Inhibitors in Patients with Non-Small Cell Lung Cancer. J. Thorac. Oncol. 2018, 13, 106-111. [CrossRef]

42. Casey, S.C.; Tong, L.; Li, Y.; Do, R.; Walz, S.; Fitzgerald, K.N.; Gouw, A.M.; Baylot, V.; Gütgemann, I.; Eilers, M.; et al. MYC regulates the antitumor immune response through CD47 and PD-L1. Science 2016, 352, 227-231. [CrossRef]

43. Hugo, W.; Zaretsky, J.M.; Sun, L.; Song, C.; Moreno, B.H.; Hu-Lieskovan, S.; Berent-Maoz, B.; Pang, J.; Chmielowski, B.; Cherry, G.; et al. Genomic and Transcriptomic Features of Response to Anti-PD-1 Therapy in Metastatic Melanoma. Cell 2016, 165, 35-44. [CrossRef]

44. Hamid, O.; Schmidt, H.; Nissan, A.; Ridolfi, L.; Aamdal, S.; Hansson, J.; Guida, M.; Hyams, D.M.; Gómez, H.; Bastholt, L.; et al. A prospective phase II trial exploring the association between tumor microenvironment biomarkers and clinical activity of ipilimumab in advanced melanoma. J. Transl. Med. 2011, 9, 204. [CrossRef]

45. Weber, R.; Fleming, V.; Hu, X.; Nagibin, V.; Groth, C.; Altevogt, P.; Utikal, J.; Umansky, V. Myeloid-Derived Suppressor Cells Hinder the Anti-Cancer Activity of Immune Checkpoint Inhibitors. Front. Immunol. 2018, 9, 1310. [CrossRef] [PubMed]

46. Chanmee, T.; Ontong, P.; Konno, K.; Itano, N.; Chanmee, T. Tumor-Associated Macrophages as Major Players in the Tumor Microenvironment. Cancers 2014, 6, 1670-1690. [CrossRef]

47. Gajewski, T.F.; Schreiber, H.; Fu, Y.-X. Innate and adaptive immune cells in the tumor microenvironment. Nat. Immunol. 2013, 14, 1014-1022. [CrossRef] [PubMed] 
48. Gray-Owen, S.D.; Blumberg, R.S. CEACAM1: Contact-dependent control of immunity. Nat. Rev. Immunol. 2006, 6, 433-446. [CrossRef] [PubMed]

49. Galluzzi, L.; Buqué, A.; Kepp, O.; Zitvogel, L.; Kroemer, G. Immunological Effects of Conventional Chemotherapy and Targeted Anticancer Agents. Cancer Cell 2015, 28, 690-714. [CrossRef]

50. Xu, X.; Huang, Z.; Zheng, L.; Fan, Y. The efficacy and safety of anti-PD-1/PD-L1 antibodies combined with chemotherapy or CTLA4 antibody as a first-line treatment for advanced lung cancer. Int. J. Cancer 2018, 142, 2344-2354. [CrossRef]

51. Kersten, K.; Salvagno, C.; De Visser, K.E. Exploiting the Immunomodulatory Properties of Chemotherapeutic Drugs to Improve the Success of Cancer Immunotherapy. Front. Immunol. 2015, 6, 516. [CrossRef]

52. Santos, E.S.; Schmidt, C.E. Treatment options after first-line immunotherapy in metastatic NSCLC. Expert Rev. Anticancer. Ther. 2020, 20, 221-228. [CrossRef]

53. Isla, D.; De Castro, J.; García-Campelo, R.; Lianes, P.; Felip, E.; Garrido, P.; Paz-Ares, L.; Trigo, J.M. Treatment options beyond immunotherapy in patients with wild-type lung adenocarcinoma: A Delphi consensus. Clin. Transl. Oncol. 2019, 22, 759-771. [CrossRef]

54. Frelaut, M.; Le Tourneau, C.; Borcoman, E. Hyperprogression under Immunotherapy. Int. J. Mol. Sci. 2019, 20, 2674. [CrossRef]

55. Russo, G.L.; Facchinetti, F.; Tiseo, M.; Garassino, M.C.; Ferrara, R. Hyperprogressive Disease upon Immune Checkpoint Blockade: Focus on Non-small Cell Lung Cancer. Curr. Oncol. Rep. 2020, 22, 41-48. [CrossRef]

56. Ferrara, R.; Facchinetti, F.; Calareso, G.; Kasraoui, I.; Signorelli, D.; Proto, C.; Prelaj, A.; Naltet, C.; Lavaud, P.; Desmaris, R.; et al. 1278P Hyperprogressive disease (HPD) upon first-line PD-1/PD-L1 inhibitors (ICI) as single agent or in combination with platinum-based chemotherapy in non-small cell lung cancer (NSCLC) patients (pts). Ann. Oncol. 2020, 31, S826. [CrossRef]

57. Kanjanapan, Y.; Day, D.; Wang, L.; Al-Sawaihey, H.; Abbas, E.; Namini, A.; Siu, L.L.; Hansen, A.; Razak, A.A.; Spreafico, A.; et al. Hyperprogressive disease in early-phase immunotherapy trials: Clinical predictors and association with immune-related toxicities. Cancer 2019, 125, 1341-1349. [CrossRef]

58. Kim, C.G.; Kim, K.H.; Lee, C.Y.; Park, S.-H.; Cho, B.C.; Shim, H.S.; Shin, E.-C.; Kim, H.R.; Pyo, K.-H.; Xin, C.-F.; et al. Hyperprogressive disease during PD-1/PD-L1 blockade in patients with non-small-cell lung cancer. Ann. Oncol. 2019, 30, 1104-1113. [CrossRef]

59. Ferrara, R.; Mezquita, L.; Texier, M.; Lahmar, J.; Audigier-Valette, C.; Tessonnier, L.; Mazieres, J.; Brosseau, S.; Leroy, L.; Duchemann, B.; et al. Fast-progression (FP), hyper-progression (HPD) and early deaths (ED) in advanced non-small cell lung cancer (NSCLC) patients (pts) upon PD-(L)-1 blockade (IO). J. Clin. Oncol. 2019, 37, 9107. [CrossRef]

60. Matos, I.; Martin-Liberal, J.; Hierro, C.; De Olza, M.O.; Viaplana, C.; Costa, M.; Felip-Falg'S, E.; Mur-Bonet, G.; Vieito, M.; Brana, I.; et al. Incidence and clinical implications of a new definition of hyperprogression (HPD) with immune checkpoint inhibitors (ICIs) in patients treated in phase 1 (Ph1) trials. J. Clin. Oncol. 2018, 36, 3032. [CrossRef]

61. Bar, J.; Ofek, E.; Barshack, I.; Gottfried, T.; Zadok, O.; Kamer, I.; Urban, D.; Perelman, M.; Onn, A. Transformation to small cell lung cancer as a mechanism of resistance to immunotherapy in non-small cell lung cancer. Lung Cancer 2019, 138, 109-115. [CrossRef]

62. Ferrara, R.; Matos, I. Atypical patterns of response and progression in the era of immunotherapy combinations. Future Oncol. 2020, 16, 1707-1713. [CrossRef]

63. Rosenberg, S.A. IL-2: The First Effective Immunotherapy for Human Cancer. J. Immunol. 2014, 192, 5451-5458. [CrossRef] [PubMed]

64. Charych, D.H.; Hoch, U.; Langowski, J.L.; Lee, S.R.; Addepalli, M.K.; Kirk, P.B.; Sheng, D.; Liu, X.; Sims, P.W.; Vanderveen, L.A.; et al. NKTR-214, an Engineered Cytokine with Biased IL2 Receptor Binding, Increased Tumor Exposure, and Marked Efficacy in Mouse Tumor Models. Clin. Cancer Res. 2016, 22, 680-690. [CrossRef] [PubMed]

65. Sharma, M.; Khong, H.; Fa'Ak, F.; Bentebibel, S.-E.; Janssen, L.M.E.; Chesson, B.C.; Creasy, C.A.; Forget, M.-A.; Kahn, L.M.S.; Pazdrak, B.; et al. Bempegaldesleukin selectively depletes intratumoral Tregs and potentiates T cell-mediated cancer therapy. Nat. Commun. 2020, 11, 1-11. [CrossRef]

66. Diab, A.; Tannir, N.M.; Bentebibel, S.-E.; Hwu, P.; Papadimitrakopoulou, V.; Haymaker, C.; Kluger, H.M.; Gettinger, S.N.; Sznol, M.; Tykodi, S.S.; et al. Bempegaldesleukin (NKTR-214) plus Nivolumab in Patients with Advanced Solid Tumors: Phase I Dose-Escalation Study of Safety, Efficacy, and Immune Activation (PIVOT-02). Cancer Discov. 2020, 10, 1158-1173. [CrossRef]

67. Sharpe, A.H.; Freeman, G.J. The B7-CD28 superfamily. Nat. Rev. Immunol. 2002, 2, 116-126. [CrossRef] [PubMed]

68. Paulos, C.M.; Carpenito, C.; Plesa, G.; Suhoski, M.M.; Varela-Rohena, A.; Golovina, T.N.; Carroll, R.G.; Riley, J.L.; June, C.H. The Inducible Costimulator (ICOS) Is Critical for the Development of Human TH17 Cells. Sci. Transl. Med. 2010, 2, 55ra78. [CrossRef]

69. Wakamatsu, E.; Mathis, D.; Benoist, C. Convergent and divergent effects of costimulatory molecules in conventional and regulatory CD4+ T cells. Proc. Natl. Acad. Sci. USA 2012, 110, 1023-1028. [CrossRef]

70. Mayes, P.A.; Hance, K.W.; Hoos, A. The promise and challenges of immune agonist antibody development in cancer. Nat. Rev. Drug Discov. 2018, 17, 509-527. [CrossRef] [PubMed]

71. Solinas, C.; Gu-Trantien, C.; Willard-Gallo, K. The rationale behind targeting the ICOS-ICOS ligand costimulatory pathway in cancer immunotherapy. ESMO Open 2020, 5, e000544. [CrossRef] 
72. Shrimali, R.K.; Yu, Z.; Theoret, M.R.; Chinnasamy, D.; Restifo, N.P.; Rosenberg, S.A. Antiangiogenic Agents Can Increase Lymphocyte Infiltration into Tumor and Enhance the Effectiveness of Adoptive Immunotherapy of Cancer. Cancer Res. 2010, 70, 6171-6180. [CrossRef]

73. Khan, K.A.; Kerbel, R.S. Improving immunotherapy outcomes with anti-angiogenic treatments and vice versa. Nat. Rev. Clin. Oncol. 2018, 15, 310-324. [CrossRef] [PubMed]

74. Kwilas, A.R.; Ardiani, A.; Donahue, R.N.; Aftab, D.T.; Hodge, J.W. Dual effects of a targeted small-molecule inhibitor (cabozantinib) on immune-mediated killing of tumor cells and immune tumor microenvironment permissiveness when combined with a cancer vaccine. J. Transl. Med. 2014, 12, 1-15. [CrossRef] [PubMed]

75. Song, E.-K.; Tai, W.M.; Messersmith, W.A.; Bagby, S.; Purkey, A.; Quackenbush, K.S.; Pitts, T.M.; Wang, G.; Blatchford, P.; Yahn, R.; et al. Potent antitumor activity of cabozantinib, a c-MET and VEGFR2 inhibitor, in a colorectal cancer patient-derived tumor explant model. Int. J. Cancer 2014, 136, 1967-1975. [CrossRef]

76. Lu, X.; Horner, J.W.; Paul, E.; Shang, X.; Troncoso, P.; Deng, P.; Jiang, S.; Chang, Q.; Spring, D.J.; Sharma, P.; et al. Effective combinatorial immunotherapy for castration-resistant prostate cancer. Nat. Cell Biol. 2017, 543, 728-732. [CrossRef]

77. Tumeh, P.C.; Hellmann, M.D.; Hamid, O.; Tsai, K.K.; Loo, K.L.; Gubens, M.A.; Rosenblum, M.; Harview, C.L.; Taube, J.M.; Handley, N.; et al. Liver Metastasis and Treatment Outcome with Anti-PD-1 Monoclonal Antibody in Patients with Melanoma and NSCLC. Cancer Immunol. Res. 2017, 5, 417-424. [CrossRef]

78. Rebuzzi, S.E.; Facchinetti, F.; Tiseo, M. Anti-angiogenesis boosts chemo-immunotherapy in patients with EGFR mutations or baseline liver metastases: Insights from IMpower150 study. Transl. Cancer Res. 2019, 8, S612-S617. [CrossRef]

79. Yamamoto, Y.; Matsui, J.; Matsushima, T.; Obaishi, H.; Miyazaki, K.; Nakamura, K.; Tohyama, O.; Semba, T.; Yamaguchi, A.; Hoshi, S.S.; et al. Lenvatinib, an angiogenesis inhibitor targeting VEGFR/FGFR, shows broad antitumor activity in human tumor xenograft models associated with microvessel density and pericyte coverage. Vasc. Cell 2014, 6, 18. [CrossRef]

80. Kimura, T.; Kato, Y.; Ozawa, Y.; Kodama, K.; Ito, J.; Ichikawa, K.; Yamada, K.; Hori, Y.; Tabata, K.; Takase, K.; et al. Immunomodulatory activity of lenvatinib contributes to antitumor activity in the Hepa1-6 hepatocellular carcinoma model. Cancer Sci. 2018, 109, 3993-4002. [CrossRef] [PubMed]

81. Brose, M.S.; Vogelzang, N.J.; DiSimone, C.; Jain, S.K.; Richards, D.A.; Encarnacion, C.A.; Rasco, D.W.; Shumaker, R.C.; Dutcus, C.E.; Stepan, D.E.; et al. A phase Ib/II trial of lenvatinib plus pembrolizumab in non-small cell lung cancer. J. Clin. Oncol. $2019,37,16$. [CrossRef]

82. Du, W.; Huang, H.; Sorrelle, N.; Brekken, R.A. Sitravatinib potentiates immune checkpoint blockade in refractory cancer models. JCI Insight 2018, 3. [CrossRef] [PubMed]

83. Percent, I.J.; Reynolds, C.H.; Konduri, K.; Whitehurst, M.T.; Nidhiry, E.A.; Yanagihara, R.H.; Nagasaka, M.; Schreeder, M.T.; Uyeki, J.; Azzi, G.; et al. Phase III trial of sitravatinib plus nivolumab vs. docetaxel for treatment of NSCLC after platinum-based chemotherapy and immunotherapy (SAPPHIRE). J. Clin. Oncol. 2020, 38, TPS9635. [CrossRef]

84. Grüllich, C. Cabozantinib: Multi-kinase Inhibitor of MET, AXL, RET, and VEGFR2. In Methods in Molecular Biology; Springer International Publishing: Cham, Switzerland, 2018; Volume 211, pp. 67-75.

85. Apolo, A.B.; Tomita, Y.; Lee, M.-J.; Lee, S.; Frosch, A.; Steinberg, S.M.; Gulley, J.L.; Schlom, J.; Bottaro, D.P.; Trepel, J.B. Effect of cabozantinib on immunosuppressive subsets in metastatic urothelial carcinoma. J. Clin. Oncol. 2014, 32, 4501. [CrossRef]

86. Nadal, R.; Mortazavi, A.; Stein, M.N.; Pal, S.K.; Lee, D.K.; Parnes, H.L.; Ning, Y.-M.; Cordes, L.M.; Bagheri, M.H.; Thompson, R.; et al. Clinical efficacy of cabozantinib plus nivolumab (CaboNivo) and CaboNivo plus ipilimumab (CaboNivoIpi) in patients (pts) with chemotherapy-refractory metastatic urothelial carcinoma (mUC) either naïve (n) or refractory (r) to checkpoint inhibitor (CPI). J. Clin. Oncol. 2018, 36, 4528. [CrossRef]

87. Schöffski, P.; Gordon, M.; Smith, D.C.; Kurzrock, R.; Daud, A.; Vogelzang, N.J.; Lee, Y.; Scheffold, C.; Shapiro, G.I. Phase II randomised discontinuation trial of cabozantinib in patients with advanced solid tumours. Eur. J. Cancer 2017, 86, 296-304. [CrossRef] [PubMed]

88. Selby, M.; Engelhardt, J.; Lu, L.-S.; Quigley, M.; Wang, C.; Chen, B.; Korman, A.J. Antitumor activity of concurrent blockade of immune checkpoint molecules CTLA-4 and PD-1 in preclinical models. J. Clin. Oncol. 2013, 31, 3061. [CrossRef]

89. Hellmann, M.D.; Paz-Ares, L.; Caro, R.B.; Zurawski, B.; Kim, S.-W.; Costa, E.C.; Park, K.; Alexandru, A.; Lupinacci, L.; De la Mora, J.E.; et al. Nivolumab plus ipilimumab in advanced non-small-cell lung cancer. N. Engl. J. Med. 2019, 381, $2020-2031$. [CrossRef] [PubMed]

90. Hellmann, M.D.; Rizvi, N.A.; Goldman, J.W.; Gettinger, S.N.; Borghaei, H.; Brahmer, J.R.; Ready, N.E.; Gerber, D.E.; Chow, L.Q.; Juergens, R.A.; et al. Nivolumab plus ipilimumab as first-line treatment for advanced non-small-cell lung cancer (CheckMate 012): Results of an open-label, phase 1, multicohort study. Lancet Oncol. 2017, 18, 31-41. [CrossRef]

91. Larkin, J.; Chiarion-Sileni, V.; Gonzalez, R.; Grob, J.-J.; Rutkowski, P.; Lao, C.D.; Cowey, C.L.; Schadendorf, D.; Wagstaff, J.; Dummer, R.; et al. Five-Year Survival with Combined Nivolumab and Ipilimumab in Advanced Melanoma. N. Engl. J. Med. 2019, 381, 1535-1546. [CrossRef]

92. Motzer, R.J.; Tannir, N.M.; McDermott, D.F.; Frontera, O.A.; Melichar, B.; Choueiri, T.K.; Plimack, E.R.; Barthélémy, P.; Porta, C.; George, S.; et al. Nivolumab plus Ipilimumab versus Sunitinib in Advanced Renal-Cell Carcinoma. N. Engl. J. Med. 2018, 378, 1277-1290. [CrossRef] 
93. Reck, M.; Mok, T.S.K.; Nishio, M.; Jotte, R.M.; Cappuzzo, F.; Orlandi, F.; Stroyakovskiy, D.; Nogami, N.; Rodríguez-Abreu, D.; Moro-Sibilot, D.; et al. Atezolizumab plus bevacizumab and chemotherapy in non-small-cell lung cancer (IMpower150): Key subgroup analyses of patients with EGFR mutations or baseline liver metastases in a randomised, open-label phase 3 trial. Lancet Respir. Med. 2019, 7, 387-401. [CrossRef]

94. Cortot, A.B.; Audigier-Valette, C.; Molinier, O.; Le Moulec, S.; Barlesi, F.; Zalcman, G.; Dumont, P.; Pouessel, D.; Poulet, C.; Fontaine-Delaruelle, C.; et al. Weekly paclitaxel plus bevacizumab versus docetaxel as second- or third-line treatment in advanced non-squamous non-small-cell lung cancer: Results of the IFCT-1103 ULTIMATE study. Eur. J. Cancer 2020, 131, 27-36. [CrossRef] [PubMed]

95. Reck, M.; Kaiser, R.; Mellemgaard, A.; Douillard, J.-Y.; Orlov, S.; Krzakowski, M.; von Pawel, J.; Gottfried, M.; Bondarenko, I.; Liao, M.; et al. Docetaxel plus nintedanib versus docetaxel plus placebo in patients with previously treated non-small-cell lung cancer (LUME-Lung 1): A phase 3, double-blind, randomised controlled trial. Lancet Oncol. 2014, 15, 143-155. [CrossRef]

96. Manegold, C.; Dingemans, A.-M.C.; Gray, J.E.; Nakagawa, K.; Nicolson, M.; Peters, S.; Reck, M.; Wu, Y.-L.; Brustugun, O.T.; Crinò, L.; et al. The Potential of Combined Immunotherapy and Antiangiogenesis for the Synergistic Treatment of Advanced NSCLC. J. Thorac. Oncol. 2017, 12, 194-207. [CrossRef]

97. Reck, M.; Garassino, M.C.; Imbimbo, M.; Shepherd, F.A.; Socinski, M.A.; Shih, J.-Y.; Tsao, A.; Lee, P.; Winfree, K.B.; Sashegyi, A.; et al. Antiangiogenic therapy for patients with aggressive or refractory advanced non-small cell lung cancer in the second-line setting. Lung Cancer 2018, 120, 62-69. [CrossRef] [PubMed]

98. Grohé, C.; Gleiber, W.; Haas, S.; Losem, C.; Mueller-Huesmann, H.; Schulze, M.; Franke, C.; Basara, N.; Atz, J.; Kaiser, R. Nintedanib plus docetaxel after progression on immune checkpoint inhibitor therapy: Insights from VARGADO, a prospective study in patients with lung adenocarcinoma. Future Oncol. 2019, 15, 2699-2706. [CrossRef]

99. Molife, C.; Hess, L.M.; Cui, Z.L.; Li, X.I.; Beyrer, J.; Mahoui, M.; Oton, A.B. Sequential therapy with ramucirumab and/or checkpoint inhibitors for non-small-cell lung cancer in routine practice. Future Oncol. 2019, 15, 2915-2931. [CrossRef]

100. Wang, Q.; Ju, X.; Wang, J.; Fan, Y.; Ren, M.; Zhang, H. Immunogenic cell death in anticancer chemotherapy and its impact on clinical studies. Cancer Lett. 2018, 438, 17-23. [CrossRef]

101. Emens, L.A.; Middleton, G. The Interplay of Immunotherapy and Chemotherapy: Harnessing Potential Synergies. Cancer Immunol. Res. 2015, 3, 436-443. [CrossRef]

102. Wang, Y.-J.; Fletcher, R.; Yu, J.; Zhang, L. Immunogenic effects of chemotherapy-induced tumor cell death. Genes Dis. 2018, 5, 194-203. [CrossRef] [PubMed]

103. Schvartsman, G.; Peng, S.A.; Bis, G.; Lee, J.J.; Benveniste, M.F.; Zhang, J.; Roarty, E.B.; Lacerda, L.; Swisher, S.; Heymach, J.V.; et al. Response rates to single-agent chemotherapy after exposure to immune checkpoint inhibitors in advanced non-small cell lung cancer. Lung Cancer 2017, 112, 90-95. [CrossRef]

104. Reck, M.; Rodríguez-Abreu, D.; Robinson, A.G.; Hui, R.; Csőszi, T.; Fülöp, A.; Gottfried, M.; Peled, N.; Tafreshi, A.; Cuffe, S.; et al. Pembrolizumab versus Chemotherapy for PD-L1-Positive Non-Small-Cell Lung Cancer. N. Engl. J. Med. 2016, 375, 1823-1833. [CrossRef]

105. Brahmer, J.R.; Rodriguez-Abreu, D.; Robinson, A.G.; Hui, R.; Csõszi, T.; Fülöp, A.; Gottfried, M.; Peled, N.; Tafreshi, A.; Cuffe, S.; et al. Progression after the next line of therapy (PFS2) and updated OS among patients (pts) with advanced NSCLC and PD-L1 tumor proportion score (TPS) $\geq 50 \%$ enrolled in KEYNOTE-024. J. Clin. Oncol. 2017, 35, 9000. [CrossRef]

106. Clinical Practice Living Guidelines-Metastatic Non-Small-Cell Lung Cancer ESMO. Available online: https:/ /www.esmo.org/ guidelines/lung-and-chest-tumours / clinical-practice-living-guidelines-metastatic-non-small-cell-lung-cancer (accessed on 6 February 2021).

107. Bluthgen, M.-V.; Besse, B. Second-line combination therapies in nonsmall cell lung cancer without known driver mutations. Eur. Respir. Rev. 2015, 24, 582-593. [CrossRef] [PubMed]

108. Canon, J.; Rex, K.; Saiki, A.Y.; Mohr, C.; Cooke, K.; Bagal, D.; Gaida, K.; Holt, T.; Knutson, C.G.; Koppada, N.; et al. The clinical KRAS(G12C) inhibitor AMG 510 drives anti-tumour immunity. Nature 2019, 575, 217-223. [CrossRef]

109. Hong, D.S.; Fakih, M.G.; Strickler, J.H.; Desai, J.; Durm, G.A.; Shapiro, G.I.; Falchook, G.S.; Price, T.J.; Sacher, A.; Denlinger, C.S.; et al. KRASG12C Inhibition with Sotorasib in Advanced Solid Tumors. N. Engl. J. Med. 2020, 383, 1207-1217. [CrossRef] [PubMed]

110. Li, B.T.; Skoulidis, F.; Falchook, G. CodeBreaK 100: Registrational Phase 2 Trial of Sotorasib in KRAS p.G12C Mutated Non-small Cell Lung Cancer. In Proceedings of the International Association for the Study of Lung Cancer 2020 World Conference on Lung Cancer, Singapore, 28-31 January 2021. virtual. Abstract PS01.07.

111. Mateo, J.; Lord, C.; Serra, V.; Tutt, A.; Balmaña, J.; Castroviejo-Bermejo, M.; Cruz, C.; Oaknin, A.; Kaye, S.; De Bono, J. A decade of clinical development of PARP inhibitors in perspective. Ann. Oncol. 2019, 30, 1437-1447. [CrossRef]

112. Mouw, K.W.; Goldberg, M.S.; Konstantinopoulos, P.A.; D’Andrea, A.D. DNA Damage and Repair Biomarkers of Immunotherapy Response. Cancer Discov. 2017, 7, 675-693. [CrossRef] [PubMed]

113. Ahn, M.-J.; Liu, Y.; Improta, T.; Marcovitz, M.; DiPiazza, K.; Lanasa, M.C. ORION: A Phase 2, randomized, multicenter, doubleblind study to assess efficacy and safety of durvalumab+olaparib vs durvalumab alone as maintenance therapy in Stage IV non-small cell lung cancer (NSCLC). J. Clin. Oncol. 2019, 37, TPS9126. [CrossRef] 
114. Heymach, J.; Thomas, M.; Besse, B.; Forde, P.M.; Awad, M.M.; Goss, G.D.; Park, K.; Rizvi, N.A.; Lao-Sirieix, S.-H.; Patel, S.I.; et al. An open-label, multidrug, biomarker-directed, multicentre phase II umbrella study in patients with non-small cell lung cancer, who progressed on an anti-PD-1/PD-L1 containing therapy (HUDSON). J. Clin. Oncol. 2018, 36, TPS3120. [CrossRef]

115. Jackson, H.J.; Rafiq, S.; Brentjens, R.J. Driving CAR T-cells forward. Nat. Rev. Clin. Oncol. 2016, 13, 370-383. [CrossRef] [PubMed]

116. Acharya, N.; Sabatos-Peyton, C.; Anderson, A.C. Tim-3 finds its place in the cancer immunotherapy landscape. J. Immunother. Cancer 2020, 8, e000911. [CrossRef] [PubMed]

117. Koyama, S.; Akbay, E.A.; Li, Y.Y.; Herter-Sprie, G.S.; Buczkowski, K.A.; Richards, W.G.; Gandhi, L.; Redig, A.J.; Rodig, S.J.; Asahina, H.; et al. Adaptive resistance to therapeutic PD-1 blockade is associated with upregulation of alternative immune checkpoints. Nat. Commun. 2016, 7, 10501. [CrossRef]

118. Davar, D.; Boasberg, P.; Eroglu, Z.; Falchook, G.; Gainor, J.; Hamilton, E. A Phase 1 Study of TSR-022, an Anti-TIM-3 Monoclonal Antibody, in Combination with TSR-042 (Anti-PD-1) in Patients with Colorectal Cancer and Post-PD-1 NSCLC and Melanoma. In Proceedings of the Society for Immunotherapy of Cancer 33rd Annual Meeting, Washington, DC, USA, 7-11 November 2018.

119. Mach, N.; Curigliano, G.; Santoro, A.; Kim, D.-W.; Tai, D.; Hodi, S.; Wilgenhof, S.; Doi, T.; Longmire, T.; Sun, H.; et al. Phase (Ph) II study of MBG453 + spartalizumab in patients (pts) with non-small cell lung cancer (NSCLC) and melanoma pretreated with anti-PD-1/L1 therapy. Ann. Oncol. 2019, 30, v491-v492. [CrossRef]

120. Joller, N.; Kuchroo, V.K. Tim-3, Lag-3, and TIGIT. Curr. Top. Microbiol. Immunol. 2017, 410, 127-156. [CrossRef]

121. Blumenthal, R.D.; Leon, E.; Hansen, H.J.; Goldenberg, D.M. Expression patterns of CEACAM5 and CEACAM6 in primary and metastatic cancers. BMC Cancer 2007, 7, 2. [CrossRef] [PubMed]

122. Brahmer, J.R.; Drake, C.G.; Wollner, I.; Powderly, J.D.; Picus, J.; Sharfman, W.H.; Stankevich, E.; Pons, A.; Salay, T.M.; McMiller, T.L.; et al. Phase I Study of Single-Agent Anti-Programmed Death-1 (MDX-1106) in Refractory Solid Tumors: Safety, Clinical Activity, Pharmacodynamics, and Immunologic Correlates. J. Clin. Oncol. 2010, 28, 3167-3175. [CrossRef] [PubMed]

123. Ribas, A.; Puzanov, I.; Dummer, R.; Schadendorf, D.; Hamid, O.; Robert, C.; Hodi, F.S.; Schachter, J.; Pavlick, A.C.; Lewis, K.D.; et al. Pembrolizumab versus investigator-choice chemotherapy for ipilimumab-refractory melanoma (KEYNOTE002): A randomised, controlled, phase 2 trial. Lancet Oncol. 2015, 16, 908-918. [CrossRef]

124. Lebbé, C.; Weber, J.S.; Maio, M.; Neyns, B.; Harmankaya, K.; Hamid, O.; O’Day, S.J.; Konto, C.; Cykowski, L.; McHenry, M.B.; et al. Survival follow-up and ipilimumab retreatment of patients with advanced melanoma who received ipilimumab in prior phase II studies. Ann. Oncol. 2014, 25, 2277-2284. [CrossRef] [PubMed]

125. Larkin, J.; Minor, D.; D'Angelo, S.; Neyns, B.; Smylie, M.; Jr, W.H.M.; Gutzmer, R.; Linette, G.; Chmielowski, B.; Lao, C.D.; et al. Overall Survival in Patients With Advanced Melanoma Who Received Nivolumab Versus Investigator's Choice Chemotherapy in CheckMate 037: A Randomized, Controlled, Open-Label Phase III Trial. J. Clin. Oncol. 2018, 36, 383-390. [CrossRef]

126. Remon, J.; Menis, J.; Aspeslagh, S.; Besse, B. Treatment duration of checkpoint inhibitors for NSCLC. Lancet Respir. Med. 2019, 7, 835-837. [CrossRef]

127. Herbst, R.S.; Garon, E.B.; Kim, D.-W.; Cho, B.C.; Perez-Gracia, J.L.; Han, J.-Y.; Arvis, C.D.; Majem, M.; Forster, M.D.; Monnet, I.; et al. Long-Term Outcomes and Retreatment Among Patients With Previously Treated, Programmed Death-Ligand 1-Positive, Advanced Non-Small-Cell Lung Cancer in the KEYNOTE-010 Study. J. Clin. Oncol. 2020, 38, 1580-1590. [CrossRef]

128. Herbst, R.S.; Baas, P.; Kim, D.-W.; Felip, E.; Pérez-Gracia, J.L.; Han, J.-Y.; Molina, J.; Kim, J.-H.; Arvis, C.D.; Ahn, M.-J.; et al. Pembrolizumab versus docetaxel for previously treated, PD-L1-positive, advanced non-small-cell lung cancer (KEYNOTE-010): A randomised controlled trial. Lancet 2016, 387, 1540-1550. [CrossRef]

129. Reck, M.; Rodríguez-Abreu, D.; Robinson, A.G.; Hui, R.; Csőszi, T.; Fülöp, A.; Gottfried, M.; Peled, N.; Tafreshi, A.; Cuffe, S.; et al. Updated Analysis of KEYNOTE-024: Pembrolizumab Versus Platinum-Based Chemotherapy for Advanced Non-Small-Cell Lung Cancer With PD-L1 Tumor Proportion Score of 50\% or Greater. J. Clin. Oncol. 2019, 37, 537-546. [CrossRef]

130. Levra, M.G.; Cotté, F.-E.; Corre, R.; Calvet, C.; Gaudin, A.-F.; Penrod, J.R.; Grumberg, V.; Jouaneton, B.; Jolivel, R.; Assié, J.-B.; et al. Immunotherapy rechallenge after nivolumab treatment in advanced non-small cell lung cancer in the real-world setting: A national data base analysis. Lung Cancer 2020, 140, 99-106. [CrossRef] [PubMed]

131. Kuczynski, E.A.; Sargent, D.J.; Grothey, A.; Kerbel, R.S. Drug rechallenge and treatment beyond progression-implications for drug resistance. Nat. Rev. Clin. Oncol. 2013, 10, 571-587. [CrossRef]

132. Petrelli, F.; Coinu, A.; Cabiddu, M.; Ghilardi, M.; Ardine, M.; Barni, S. Platinum rechallenge in patients with advanced NSCLC: A pooled analysis. Lung Cancer 2013, 81,337-342. [CrossRef]

133. Ardizzoni, A.; Tiseo, M.; Boni, L.; Vincent, A.D.; Passalacqua, R.; Buti, S.; Amoroso, D.; Camerini, A.; Labianca, R.; Genestreti, G.; et al. Pemetrexed Versus Pemetrexed and Carboplatin As Second-Line Chemotherapy in Advanced Non-SmallCell Lung Cancer: Results of the GOIRC 02-2006 Randomized Phase II Study and Pooled Analysis With the NVALT7 Trial. J. Clin. Oncol. 2012, 30, 4501-4507. [CrossRef] [PubMed] 